Fascism, Imperialism and International Law: An Arch Met a Motorway and the Rest is History...

\author{
Rose Parfitt \\ Lecturer in Law, Kent Law School; \\ Australian Research Council Discovery(DECRA) Research Fellow, Melbourne Law School
}

\begin{abstract}
What would happen to our understanding of international law and its relationship with violence if we collapsed the distinction between our supposedly post-colonial 'present' and its colonial 'past'; between the sovereign spaces of the twenty-first century global order, and the integrated, hierarchical space of fascist imperialism? I respond to this question through an investigation into the physical contours of a precise 'imperial location': $30^{\circ} 31^{\prime} 00^{\prime \prime} \mathrm{N}, 18^{\circ} 34^{\prime} 00^{\prime \prime} \mathrm{E}$. These coordinates refer to a point on the sea-edge of the Sirtica that is occupied, today, by the Ra's Lanuf oil refinery, one of Libya's three most important such facilities. In the late-1930s, however, during Libya's period of fascist colonial rule, this was the spot at which a state-of-the-art motorway, the Via litoranea libica, was crossed by a giant triumphal arch, the Arco dei Fileni. Through a chronotopic reading of the temporal, spatial and interpellative aspects of this point, its architecture and its history, I suggest that fascist lawyers, officials and intellectuals accepted an unfortunate truth about the relationship between international law and violence - a relationship that twenty-first century doctrinal international law is loath to confront. This truth concerns the inherently expansionist logic of the sovereign state, and the inevitably hierarchical ordering of the 'international community' which stems from it.
\end{abstract}

Acknowledgements: I am incredibly grateful to many friends, colleagues, workshops and institutions for their contribution to the thinking that went into this article. In particular, I would like to thank the members of the Imperial Locations workshop at the Eric Castrén Institute at Helsinki Law School; the Institute for International Law and the Humanities and the Legal Theory Workshop, both at Melbourne Law School; the Diagnosing Legal Temporalities workshop at Kent Law School; the Institute for Global Law and Policy at Harvard Law School. I owe a special debt of gratitude to Noha Aboueldahab, Nesrine Badawi, Lauren Benton, Maddy Chiam, Geoff Gordon, Emily Grabham, Richard Joyce, Sara Kendall, Martti Koskenniemi, John Morss, Sara Paton, David Parfitt, Alice Riccardi, Lulu Weis, and to my co-collaborators - Luigi Nuzzo, Liliana Obregón, Kerry Rittich and, in particular, Luis Eslava. I would also like to acknowledge the Australian Research Council, which funded this research. The views expressed here are all my own, as are the mistakes. 


\title{
Fascism, Imperialism and International Law: An Arch Met a Motorway and the Rest is History...
}

\author{
Rose Parfitt \\ Full Name: Ra's Lānūf (Approved - A) [Ra's Lanuf: Variant - V] \\ Primary Country Code: LY (Libya) \\ Region Font Code (RC): 3 (Africa/Middle East) \\ Latitude in degrees, minutes, and seconds: $30^{\circ} 31^{\prime} 00 " \mathrm{~N}$ \\ Longitude in degrees, minutes, and seconds: $18^{\circ} 34^{\prime} 00^{\prime \prime} \mathrm{E}$ \\ Military Grid Reference System (MGRS) coordinates: 34RBU6650278557 \\ Populated Place Classification (PC): No data. \\ US National Geospatial-Intelligence Agency, $2018 .{ }^{1}$ \\ '[T]he place calls the event to mind.' \\ Sallust, The Jugurthine War, Ch. LXXIX, 'Philæni' [86 - c.35 BCE].
}

\section{Introduction: Location.}

Scattered about, somewhat incongruously, in an archaeological enclosure not far from the Libyan town of Ra's Lanuf one can find the remains of a triumphal arch. This arch, the Arco dei Fileni, was commissioned in 1937 by the Governor-General of Libia Italiana, Italo Balbo, and designed by Florestano di Fausto, perhaps the most celebrated of fascist Italy's colonial architects. One of fascism's most famous monuments, the Arco also straddled one its greatest technological achievements, ${ }^{2}$ the Via litoranea libica - the motorway which ran between its piers just at the point where the Tripolitania/Cyrenaica border met the sea-edge of the Sirtica desert: point $30^{\circ} 31^{\prime} 00^{\prime \prime} \mathrm{N}$, $18^{\circ} 34^{\prime} 00 " \mathrm{E}$.

Completed in the aftermath of the brutal suppression of the Libyan resistance movement after two decades of bitter struggle, ${ }^{3}$ the Litoranea ran for $1,800 \mathrm{~km}$ along the entire coastline of the colony, from the French protectorate of Tunisia in the west to the British protectorate of Egypt in the east. In doing so, it provided Italy with a concrete (in every sense) symbol of its now total control over these three recalcitrant North African territories. Viewed in the light of Italy's merciless annexation of the Ethiopian Empire less than a year before, ${ }^{4}$ contemporary commentators were correct to point out that the Litoranea was, in fact, 'nothing but a military highroad thinly camouflaged

\footnotetext{
${ }^{1}$ US National Geospatial-Intelligence Agency, at http://geonames.nga.mil/

2 J. L. Wright 'Mussolini, Libya and the Sword of Islam' in R. Ben-Ghiat \& M. Fuller (eds.), Italian Colonialism (2005), 121 at 122.

${ }^{3}$ See e.g. A. A. Ahmida The Making of Modern Libya: State Formation, Colonization, and Resistance, 18301932 (1994) 103-40; N. Labanca La Guerra italiana per la Libia, 1911-1931 (2012).

${ }^{4}$ See R. S. Parfitt 'Empire des nègres blancs: The Hybridity of International Personality and the Abyssinia Crisis of 1935-36', 24 LJIL (2011) 849-872.
} 
as a road to encourage the motoring tourist'. ${ }^{5}$ The Arch complemented this monumentalisation of Italy's hard-won domination over Cyrenaica, Tripolitania and Fezzan. These three historically separate and culturally distinct territories had first been sized by (liberal) Italy in the Italo-Ottoman War of 1911-1912. However, the latter's hold, particularly over Fezzan, had remained tenuous. It was the fascist administration which in 1934 merged them together officially into a single colony known as Italian North Africa, or 'Italian Libya'. ${ }^{6}$

The Arco was unveiled on 16 March 1937 in a grand ceremony to mark the opening of the Litoranea - a ceremony presided over by Mussolini himself. And there it stood, with only the whistling of the ghibli winds for company, for nearly 40 years - the only visible structure for miles around. The Litoranea (now better known as the Libyan Coastal Highway or الطريق الساحلي الليبي) is still in use primarily by tank trucks and other traffic, or more commonly by the battered Toyota pickups favoured by the various militia which have been struggling, since 2011, to gain control over the area, home to some of the largest oilfields in the world, and in particular over the gigantic Ra's Lanuf refinery which now dominates the landscape. For the Arco is today no more, having been blown up in 1974 by Muammar Qaddafi, then Revolutionary Chairman of the Libyan Arab Republic. All that remains to mark the spot at which it once crossed the motorway are traces of its concrete foundations, which (at least in 2009) could still 'just be made out in the road surface, close to the west end of the one of the airstrips at Ra's Lanuf'. ${ }^{7}$

The conflict over this small area of land, now home to Libya's third-largest oil refinery, has been fierce ever since the revolution which ousted Qaddafi in October 2011. The Ra's Lanuf refinery has changed hands many times - first passing from 'regime loyalists' to 'rebel forces' backed by NATO airstrikes authorised (under UN Security Council 1973 of March 2011) to enforce the international community's 'responsibility to protect' Libyan civilians; ${ }^{8}$ then, from August 2014 onwards, from one rival faction to another in Libya's increasingly complex and violent civil war. Most recently, these factions have included the Islamic State of Iraq and the Levant (IS), which took control of the facility in January 2016, setting fire to four of its storage tanks; the once official, now rogue Petroleum Facilities Guard (PFG) which ousted IS; the 'Operation Dignity' forces of the Libyan National Army (LNA), commanded by General Khalifa Haftar, which ousted the PFG, ${ }^{9}$ and the Defence of Benghazi Brigades, with whom Dignity forces continue to spar. ${ }^{10}$

Some of these factions are allied with one of Libya's three rival governments: the General National Congress (GNC) established in 2012 in Tripoli (now a rump organisation known as the

\footnotetext{
${ }^{5}$ M. H. H. MacCartney \& P. Cremona Italy's Foreign and Colonial Policy, 1914-1937 (1938) 4.

${ }^{6}$ P. Kenrick Tripolitania (2009) 154.

7 Ibid., at 156.

8 UN Doc. S/RES/1973 (2011), para. 1. See A. Orford, 'What Kind of Law is This? LRB Blog, 29 Mar. 2011; ibid, International Authority and the Responsibility to Protect (2011).

9 'Dignity Operation Forces Recapture Ras Lanuf Oil Port,' Libya Observer, 14 Mar. 2017.

10 'Benghazi Defense Brigades Capture Ras Lanuf Airport in Central Libya,' Libya Observer, 3 Mar. 2017.
} 
Government of National Salvation); the rival House of Representatives which fled to Tobruk in mid2014 after members of the original GNC rejected the results of the June 2014 elections; and the Government of National Accord established in December 2015 under the UN-brokered 'Skhirat Agreement', now also based in Tripoli. ${ }^{11}$ For example, Hafta's LNA is (generally) supported by the House of Representatives - in theory (not in practice) the legislative arm of the GNA. Many of these militias also have external backing. For instance, in September 2016, Dignity forces seized back control of the refinery from the PFG supported by Egyptian and UAE airstrikes, ${ }^{12}$ and Russia is liaising with Haftar directly, ${ }^{13}$ in spite the latter's vociferous opposition to the Skhirat Agreement. ${ }^{14}$ The US has been launching regular airstrikes in Libya against 'IS militants' since August $2016 .{ }^{15}$ In the midst of this confusion of conflicting jurisdictional claims and aerial bombardment, it is difficult to confirm whether the bumps in the tarmac left by the remnants of the Arch are still visible.

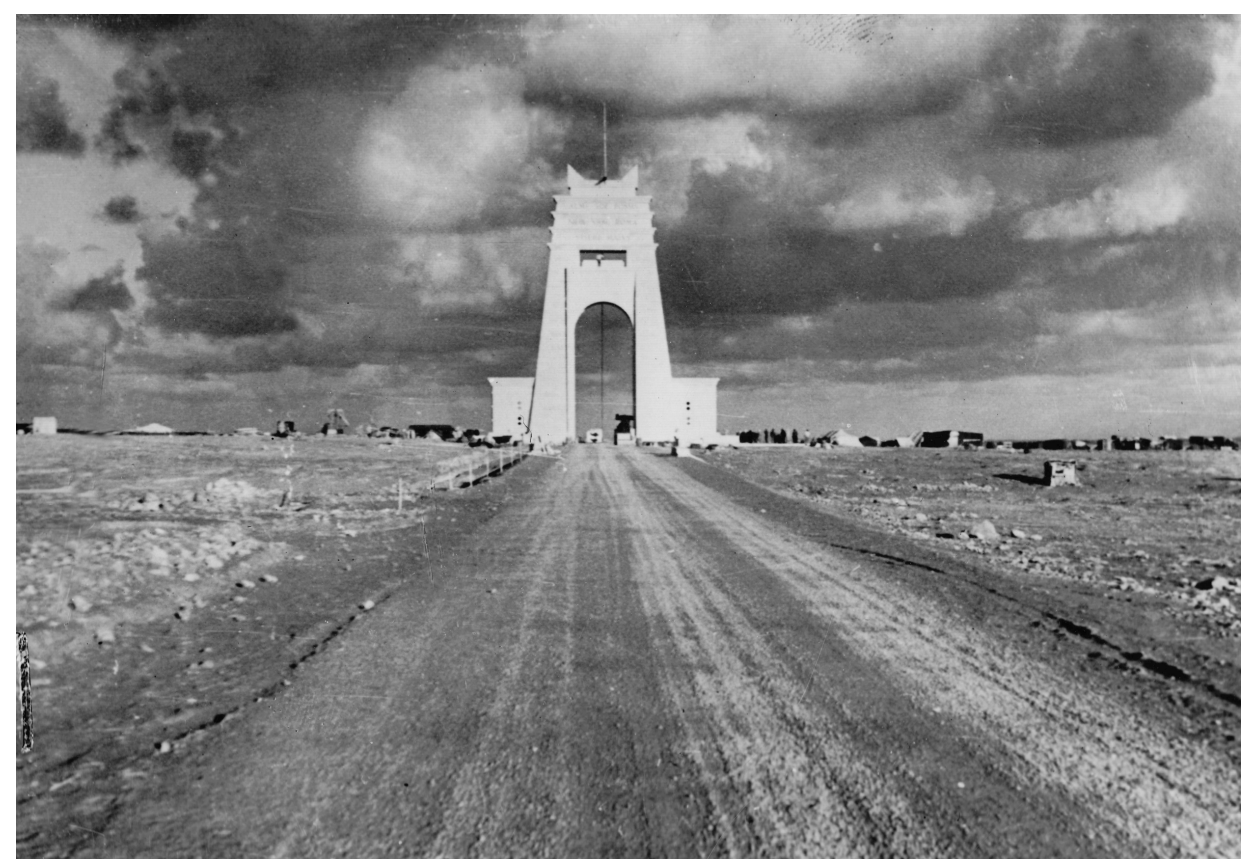

Figure 1: The Arco dei Fileni and the Via litoranea libica. Nazi propaganda image, 23 Sep. 1940. Photo: Berliner Verlag/Archiv @ DPA Picture Alliance/Alamy Stock Photo.

So, what are scholars of international law to make of the fact that these two structures - on the one hand, a monument to the opening of a road symbolising the integration and militarisation of a fascist colony on the one hand; on the other, an oil refinery at the centre of a civil conflict which

\footnotetext{
${ }^{11}$ See M. Fitzgerald \& M. Toaldo, A Quick Guide to Libya's Main Players, European Council for Foreign Relations, at www.ecfr.edu

12 'Foreign Airstrikes Rescue Dignity Operation Militias Again', Libya Observer, 18 Sep. 2016.

${ }^{13}$ M. Tsvetkova, 'Exclusive: Russian Private Security Firm says it had Armed Men in East Libya', Reuters, 11 Mar. 2017.

${ }^{14} \mathrm{~A}$. al-Warfalli, 'East Libyan Commander Haftar says UN-Backed Government Obsolete, Hints may Run in Elections', Reuters, 17 Dec. 2017.

${ }^{15}$ E Schmitt, 'Under Trump, U.S. Launched 8 Airstrikes Against ISIS in Libya. It Disclosed 4', New York Times, 8 Mar. 2018.
} 
has erupted in the wake of an international intervention executed by the self-styled agents of humanity's 'protection' - occurred, more than eight decades apart, in exactly the same 'location'? The answer is not straightforward.

On the one hand, international law's core doctrines are inclined to assure us that this is nothing but a coincidence: $30^{\circ} 31^{\prime} 00^{\prime \prime} \mathrm{N}, 18^{\circ} 34^{\prime} 00^{\prime \prime E}(1937)$ and $30^{\circ} 31^{\prime} 00^{\prime \prime} \mathrm{N}, 18^{\circ} 34^{\prime} 00^{\prime \prime E}$ (today) might be identical in spatial terms, these doctrines suggest, but time holds them safely apart. To give just a few illustrations, the doctrine of sovereign equality (as rearticulated in Resolution 1973) insists that international law is founded on a 'strong commitment' to the 'sovereignty, independence, territorial integrity and national unity' of all states. ${ }^{16}$ Similarly, the doctrine of the non-use of force is often traced to the defeat of official fascism in 1945, together with its efforts to justify the use of force on the basis of the need for spazzio vitale or Lebensraum ('living space'). ${ }^{17}$ Equally, the emergence of the nowcustomary right of 'all peoples' to self-determination in the 1960 s and 70 s is understood to have rendered colonialism unlawful in much the same way as fascist expansionism did. ${ }^{18}$ As these illustrations indicate, from a doctrinal perspective the progress of international law away from territorial expansionism (whether fascist or colonial) and towards sovereign equality has been such that the 'present' conflict in Libya (an independent state since 1951) can be assumed to be wholly unconnected with the 'historical' phenomenon of fascist imperialism. ${ }^{19}$

On the other hand, however, our faith (as scholars of international law) in the idea that international law's trajectory will inevitably be 'progressive' is not what it once was. Official bodies like the International Court of Justice continue to go about their work of deriving the current state of international law from the sources laid down by Article 38(1) of the ICJ Statute. Yet that method has been subjected to a thoroughgoing critique in recent years. That critique has taken on an important temporal dimension, with scholars seeking not only to contextualise international law's 'evolution' (for example, by drawing out the discipline's colonial origins) but also to bring those 'past' origins to bear on international law's ostensibly post-colonial 'present'. ${ }^{20}$ With this, critical scholars are increasingly challenging both the teleological temporality of doctrinal international law (the idea that the more international law we have, the better the world will be) and the historicist temporality of mainstream history (generally suspicious of any effort that might be construed as sullying the

\footnotetext{
${ }^{16}$ Res. 1973, supra note 8, Preamble

171945 Charter of the United Nations 1 UNTS XVI, Art. 2(4); Military and Paramilitary Activities in and Against Nicaragua (Nicaragua v. United States), Merits, Judgment of 27 June 1986, [1984] ICJ Rep. 1986 at 14, para. 188. See e.g. M. E. O'Connel, 'Peace and War', in B. Fassbender \& A. Peters (eds.), The Oxford Handbook of the History of International Law (2012), 272 at 291.

${ }^{18}$ UN Doc. A/RES/1514(XV) (1960); Legal Consequences for States of the Continued Presence of South Africa in Namibia (South West Africa) notwithstanding Security Council Resolution 276 (1970), Advisory Opinion of 21 Jun. 1971, ICJ Rep. 1971 at 16, para 52.

${ }_{19}$ See e.g. A. Cassese, International Law $2^{\text {nd }}$ ed. (2005), 37; M. N. Shaw, International Law, $5^{\text {th }}$ ed. 2003), 30; P. Malanczuk, Akehurst's Modern Introduction to International Law, $7^{\text {th }}$ Ed. (1997), 25.

20 See e.g. A. Anghie Imperialism, Sovereignty and the Making of International Law (2004); G. Simpson Great Powers and Outlaw States: Unequal Sovereigns in the International Legal Order (2004).
} 
remnants of yesterday with the concerns of today). ${ }^{21}$ From the perspective of this new, critical international legal temporality - far more elastic than either of its linear (teleological and historicist) counterparts - to insist that two events are necessarily held apart by a distinction between 'past' and 'present' is, indeed, a product of ideology. ${ }^{22}$ The same, indeed, might be said about the spatiality of international law. Where the doctrine tends to narrate the division of the world into a series of formally equal states simply as a fact of life, if not as an inevitable and inherently emancipatory development, critical scholars of international law, and Indigenous scholars in particular, have challenged this assumption that statehood is a neutral, natural and universal way to organise collective life. ${ }^{23}$

Building on this body of scholarship, the question I want to explore in this essay is what would happen if we were to collapse the distinction between the (post-colonial) 'present' and (colonial) 'past' - and between 'sovereign' and 'imperial' space - in relation, specifically, to fascist colonialism? My jumping-off point, here, concerns the situation, both paradoxical and catastrophic, which began to unfold with the passage of Resolution 1973, under the aegis of which the 'international community' authorised the sacrifice of (in the end) between 10,000 and 25,000 Libyan lives in the name of their own 'protection'. ${ }^{24}$ Rather than approaching international legality as something that regulates the relations among a set of bounded jurisdictions know as states (together with certain other 'international personalities'), I will read international law here as something that can (still) be found embedded in, and rebounding from, the physicality of a particular location, contributing to the constitution of particular kinds of subjectivity. This location I will examine here is, of course, point $30^{\circ} 31^{\prime} 00^{\prime \prime} \mathrm{N}, 18^{\circ} 34^{\prime} 00^{\prime \prime} \mathrm{E}$, home of the former Arch, of the still-existent Ra's Lanuf refinery, and of their tenacious companion, the Litoranea/Libyan Coastal Highway.

The approach I develop here in order to respond to this question is at once materialist and chronotopic. Regarding the first, I follow my co-contributor Luis Eslava in understanding the normative force of international law to be something that operates not only through in its documents and institutions, but also through the physical contours of our daily existence: the design of our homes; the materials of which our monuments are constructed; animals and vehicles which carry us about; the fabric of our clothes; the sandiness or otherwise of our soil. ${ }^{25}$ Regarding the second, I

\footnotetext{
${ }^{21}$ A. Orford, 'On International Legal Method', 1 London Review of International Law (2013), 166; R Parfitt 'The Spectre of Sources' 25 EJIL (2014), 297.

22 See, most famously, C. Schmitt [1950], The Nomos of the Earth in the International Law of the Jus Publicum Europaeum (2006).

${ }^{23}$ See e.g. A. Simpson, Mohawk Interruptus: Political Life Across the Borders of Settler States (2014).

24 These figures come from Cherif Bassiouni, head of the April 2011 UN Human Rights Council mission to Tripoli and rebel-held areas ('Up to 15,000 Killed in Libya War: UN Rights Expert, Reuters, 10 Jun. 2011) and US senator John McCain reporting figures from the National Transitional Council (in Rory Mulholland \& Jay Deshmukh, 'Residents flee Gaddafi hometown', Sydney Morning Herald, 3. Oct. 2011) respectively. See Orford, supra note 8; A. Çhubukçhu, 'The Responsibility to Protect: Libya and the Problem of Transnational Solidarity', 12 Journal of Human Rights (2013), 40.

${ }^{25}$ L. Eslava Local Space, Global Life: The Everyday Operation of International Law and Development (2015); L. Eslava, 'The Materiality of International Law: Violence, History and Joe Sacco's The Great War', London Review of International Law (2017), 49.
} 
follow the linguistic philosopher and semiotician Mikhail Bakhtin in understanding subjectivity as a function of the narrative relationship between time and space. ${ }^{26}$ Bringing these two approaches together, the task of this article will be to work out what kinds of subjects the materiality of point $30^{\circ} 31^{\prime} 00^{\prime \prime} \mathrm{N}, 18^{\circ} 34^{\prime} 00^{\prime \prime} E$ produced in the 1930s, and what kinds of subjects it continues to produce today. In Section 1, I focus on the temporality of this location. In Section 2, I address its spatiality. In Section 3, turn to the question of subjectivity. Somewhat disconcertingly, the results produced by this approach suggest that fascism's understanding of self-determining subjectivity ('sovereignty') as inherently expansionist, hierarchical and violent may have been more accurate than its liberal counterpart, more familiar to doctrinal international law today. Uncomfortable as this suggestion may be, however, it does a certain kind of light on the otherwise puzzling tendency of an international legal order committed to the development of 'friendly relations among nations based on respect for the principle of equal rights and self-determination of peoples' to promote violence rather than to prevent it. $^{27}$

\section{Time.}

As its location and aesthetics proclaimed, the Arco dei Fileni was intended to symbolise Italy's right to traverse, at will, a frontier that was at once political and temporal. Libya's Cyrenaica-Tripolitania boundary had itself been superimposed on top of the ancient border between the Phoenician colony of Carthage (founded in 814 or 815 BCE) and the Greek colony of Cyrene (founded in 630 BCE). ${ }^{28}$ It was the memory of ancient border that the Arch's two eponymous figures, cast in bronze and lodged in its attic (see Fig. 2), were intended to evoke. The legend of that desert frontier is described by the Governor of the Roman colony Africa Nova, Sallust (86-34 BCE) in his famous account, The War with Jugurtha. The Phileni twins, two Carthaginians, Sallust relates, had been buried alive after patriotically agreeing to give up their lives in order to preserve the more advantageous border they had just won in a race against two Cyrenaicans. It is impossible to know, according to Sallust, whether the twins lost the race 'due to sloth or chance'; for 'in those lands... when the wind rises on

\footnotetext{
${ }^{26}$ M. Bakhtin, 'Forms of Time and the Chronotope in the Novel' in M. Holquist (ed), The Dialogic Imagination: Four Essays by M. M. Bakhtin, trans. C. Emerson \& M. Holquist (1981), 84; M. Bakhtin, 'The Bildungsroman and its Significance in the History of Realism', in C Emerson \& M. Holquist (eds.) Speech Genres and Other Late Essays, trans. V. W. McGee (1986), 10. For a more developed account of this methodology, see R. S. Parfitt 'Newer is Truer: Time, Space, and Subjectivity at the Bandung Conference', in L Eslava, M Fakhri \& V Nesiah, Bandung, Global History and International Law: Critical Pasts and Pending Futures (2018), 49. For a different application, see M. Valverde Chronotopes of Law: Jurisdiction, Scale and Governance (2015).

${ }^{27}$ UN Charter, supra note 17, Art. 1.

${ }^{28}$ Kendrick, supra note 6, at 156.
} 
those level and barren plains, it sweeps up the sand from the ground and drives it with such violence as to fill the mouth and eyes'. ${ }^{29}$

That the governors of the much later colony of Libia Italiana should have chosen an ancient name (from the Greek word $\Lambda$ ıún, Libyē) and ancient myth as the theme of a monument to their power is, of course, unsurprising. The willingness of the Mussolini regime to portray Italy as the Roman Empire's rightful inheritor at every available opportunity is well known, ${ }^{30}$ although it was hardly a fascist innovation, as Gabriele D'Annunzio's blood-spattered poems celebrating the Islamophobic carnage of the first 'Libyan War' of 1911-12 (see Fig. 3) remind us. ${ }^{31}$ However, as the choice of the legend of the Phileni twins indicated, no less than the eclectic mix of Roman, Pharonic, Phoenician and Hellenistic elements that went into the Arch's design, ${ }^{32}$ fascist imperialism in Italy claimed not only to the legacy of the Roman Empire as its patrimony, but actually to the whole of antiquity.

After Mussolini's seizure of power in 1922, this temporally expansionist claim came to be expressed more obviously in Libya's built environment. Central to the 'colonial modern' architectural style which emerged in the late 1920s and early 30s was the concept of Mediterraneanità ('Mediterraneanness'), vigorously discussed in Italian architectural journals during this period. ${ }^{33}$ As the anthropologist and architectural historian Mia Fuller explains, la Mediterraneanità allowed architects like di Fausto to incorporate elements of the Arab 'vernacular' into their buildings with the claim that, far from representing a degrading act of mimesis in relation to a supposedly inferior culture, such incorporation spoke, rather, of the 'conclusion' of the 'eternal task of Latinità [Latineity]'. ${ }^{34}$ According to the designer Carlo Enrico Rava, for example, Italian architects working in this style were not borrowing from Arab culture but reasserting and 'perpetuat[ing] the work of Rome, creating the new in its traces... [so as to] renew and complete the still primitive local architecture of our colony, with all the most modern technical and practical innovations'. They were, he said,

[t]he fated, centuries-old vessels...of...this eternal Latin spirit...a whole vernacular architecture that is typically Latin and belongs to us, that is without age and yet is extremely Rational, that is made of white, smooth cubes and large terraces that is Mediterranean and solar, seems to be showing us the way to retrieve our most intimate essence as Italians. Our

${ }^{29}$ G. S. Sallust [86 - c.35 BCE], The War with Jugurtha, $2^{\text {nd }}$ Ed, trans. Bill Thayer (1931), para. 79. See also J. Quinn 'Libya's Ancient Borders' LRB Blog, 17 Mar. 2014.

${ }^{30}$ See e.g. P. Melgrani 'The Cult of the Duce in Mussolini's Italy', 11 Journal of Contemporary History (1976), 221 at 229-30.

${ }^{31}$ See e.g. G. D’Annunzio, 'La Canzone del sangue', in A. Andreoli \& N. Lorenzini (eds.), Gabriele D'Annunzio, Versi d'amore e di gloria, Vol. II (1984), 659. See L. Re 'Italians and the Invention of Race: The Poetics and Politics of Difference in the Struggle over Libya, 1890-1913', 1 California Italian Studies (2010), at 26.

${ }^{32}$ Kenrick, supra note 6, at 154 .

${ }^{33}$ M. Fuller, Moderns Abroad: Architecture, Cities and Italian Imperialism (2007), 107-35.

${ }^{34}$ C. E. Rava quoted ibid, 117. 
race, our culture, our civilization both ancient and new, are Mediterranean: thus it is this 'Mediterranean spirit' that we should seek the characteristic of Italianità [Italianness]... ${ }^{35}$

Both in theory and in practice, then, the materiality of daily existence echoed and reflected back the legal changes that were being enacted in Libya under the fascist colonial administration - changes that included the merciless 'pacification' (in 1931) of the Libyan resistance movement, and the joint incorporation of Cyrenaica and Tripolitania (though not Fezzan) into the Italian state (in 1939) to become its nineteenth region (as in French Algeria).

The Arco dei Fileni was, of course, hardly the minimalist 'white, smooth cube' characteristic of the iconic villaggi di colonizzazione then under construction all over Libya (see Fig. 4). Contrasting sharply with their emphasis on pure functionality, the Arch displayed, among other decorations, an inscription in huge capital letters, ${ }^{36}$ the enormous bronzes of the Phileni twins 'evidently writhing in distress', ${ }^{37}$ and two elaborately carved reliefs. ${ }^{38}$ In other ways, however, the Arch exemplified at least di Fausto's particular 'visione mediterranea', ${ }^{39}$ as this was embodied in the eclectic (to the point of kitsch) style for which his buildings remain famous. ${ }^{40}$ Standing $30.85 \mathrm{~m}$ tall, built of concrete (that most modernist of materials) and faced with 350 tonnes of travertine (that whitest and most Roman of limestones), ${ }^{41}$ the Arch's very physicality married the classical and the modern together, allowing it to operate as a kind of temporal tunnel between one and the other. This effect was reinforced by the fact that it was an arch - that marker of 'all things classical, powerful, and historically legitimate', ${ }^{4}$ or, in di Fausto's words, 'a thing entirely our own' (as Italians), through which 'buildings become dimensions of the [Italian] spirit'. ${ }^{43}$ Its rich decorations were, moreover, visible only at close range. From any distance, its overwhelming impression (see Fig. 2) would have been one of massive, white, geometric simplicity.

\footnotetext{
${ }^{35}$ C. E. Rava quoted ibid, 105.

${ }^{36}$ From the poet Horace praising the Emperor Augustus: Alme Sol possis nihil Urbe Roma visere maius ['O fostering Sun, may you never see anything greater than the City of Rome'].

${ }^{37}$ Kenrick, supra note 6, at 155.

38 Ibid.

${ }^{39}$ F. di Fausto 'Visione mediterranea della mia architettura', 1 Liba (1937), 16.

${ }^{40}$ Fuller, supra note 33, at 129; B. L. McLaren, 'Architecture of Tourism in Italian Libya' in Ben-Ghiat \& M.

Fuller (eds.), supra note 2, 167 at 171-73.

${ }^{41}$ Kenrick, supra note 6 , at 154.

42 Fuller, supra note 33, at 130.

${ }^{43}$ Di Fausto, supra note 39, at 18.
} 


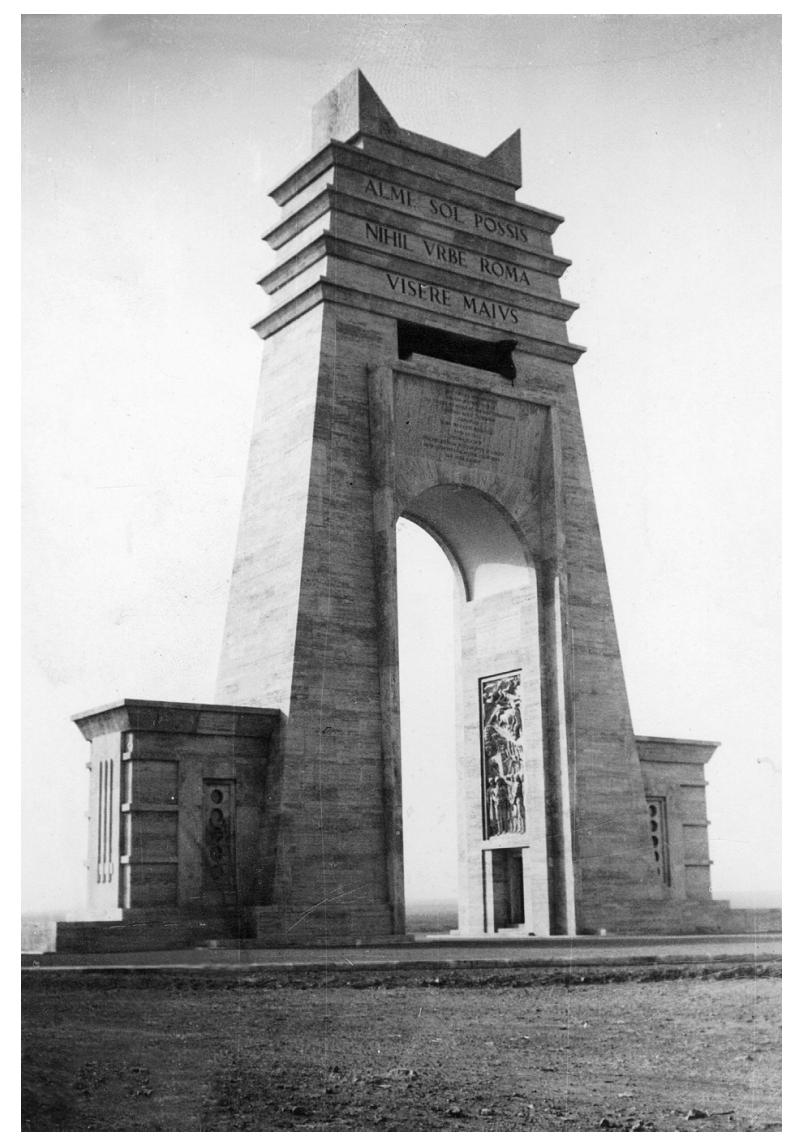

Figure 2: The Arco dei Fileni. Nazi propaganda image, 1937 @ Photo: Sueddeutsche Zeitun/Alamy Stock Photo.

The form of the Arch, then, aimed clearly at underscoring Italy's claim to these territories through the enactment of a fold in the linear sequence of centuries to bring Libya's periods of classical and fascist rule together. But the memorial effect of this temporally twofold imperial international order was to obscure another one: that of the Islamic dar al-Islam to which, from the seventh century CE until 1912, Tripolitania, Cyrenaica and Fezzan had been assimilated. In effect, the concept of mediterraneità, as expressed in the Arch, wiped out nearly 400 years of Ottoman rule and thirteen centuries of Islamic political and territorial authority in Libya. ${ }^{44}$ In doing so, it gave material form to fascism's colonisation not only of the area traversed by these territories, but of their past as well.

Though hardly 'functionalist', the Arco dei Fileni did have a function, however: that of marking the border between the two coastal regions which the Litorana Libica hemmed together. When observed (as it would have been) in conjunction with this motorway, therefore, the Arch's otherwise retrospective sense of direction must have clashed spectacularly with the road's undeniably high-

\footnotetext{
${ }^{44}$ A. Abel, 'Dār al-Islām' in P. Bearman et al (eds.), Encyclopaedia of Islam, $2^{\text {nd }}$ Ed., at referenceworks. brillonline.com
} 
tech, futuristic orientation. Such an orientation was, of course, no less in keeping with the aesthetics and politics of Italian fascism than its neo-classical inclinations. Just as they sought to 'trim the bourgeois fat' from the bodies and minds of Italians, so the ideologues and institutions of the Mussolini regime sought to eliminate all that was 'barbaric' and 'decadent' about the previous era. ${ }^{45}$ The Duce frequently referred, for example, to the 'stale breath of the past', 'exhaled' by the institutions of parliamentary democracy, ${ }^{46}$ going so far as to recalibrate the calendar to begin on 29 October 1922, the day after the March on Rome. ${ }^{47}$ Indeed, as historians of art, in particular, have pointed out, far from being a contradiction, this juxtaposition of past and present was a distinctive and politically highly-charged element of fascist aesthetics. As the art historian Mark Antliff argues, citing many other examples of this combination, fascism's 'rejenerative nationalism' was notably 'Janus-faced':

[T]o reinvigorate the body politic, fascists looked beyond a decadent present to past eras, but they did not advocate a nostalgic return to, say, the era of Imperial Rome. Instead, they sought to incorporate qualities associated with past eras into the creation of a radically new society, fully integrated with twentieth-century industrialism and technology. In Sorelian fashion, selective moments from a nation's historical past were utilized for their mythic appeal as a catalyst for the radical transformation of present society. ${ }^{48}$

Understood in this physical and historical context, the Litoranea offered one of the most tangible symbols of fascism's self-understanding as the agent of an industrialised, technified, corporatist and hence truly modern future. And it was of course in this self-understanding that fascism's notable debt to the art movement known as Futurism was most clearly visible.

A few years younger than Futurism, whose founding manifesto dates from $1909,{ }^{49}$ fascism emerged in 1914 into a highly charged political and aesthetic atmosphere already coloured by highly disruptive Futurist agitation. Witness, for example, the following account of a speech made in 1913, at the conclusion of the Italo-Ottoman War, by Futurism's leader, Filippo Tommaso Marinetti:

We want an Italy that is sovereign and absolute! ... The word Italy must prevail over the word 'freedom'...

(Applause. Ten minutes of pandemonium)...

\footnotetext{
${ }^{45}$ M. Dyal, 'Mussolini's New Fascist Man', Counter-Currents.com, 16 Oct. 2012.

${ }^{46}$ B. Mussolini 'Address to the National Corporative Council', 14 Nov. 1933, in J. T. Schnapp, A Primer of Italian Fascism, trans. J. T. Schnapp, O. E. Sears \& M. G. Stampino (2000), 154 at 163.

${ }^{47}$ B. Spackman, 'Fascist Purility', 13 Qui Parle (2001), 13 at 24.

${ }^{48}$ M. Antliff, 'Fascism, Modernism, and Modernity', 84 The Art Bulletin (2002), 148 at 150.

${ }^{49}$ F. T. Marinetti [1909], 'The Founding and Manifesto of Futurism', in L. Rainey et al (eds. and trans.), Futurism: An Anthology (2009), 29.
} 
$[A] \| l$ necessary money, brutality, and blood for the vigorous, practical completion of this Libyan exploit. This completion is today the colonial Futurism of Italy. I end with the cry of 'Libya Forever!'

(Shouts. Cries of 'Libya Forever!' Applause. Indescribable confusion. Arguments, scuffles, fisticuffs, punches slaps, invasion by the carabinieri) ${ }^{50}$

Although Futurism's momentum had peaked long before 1937, fascism had by that time appropriated - and pastiched - many of Futurism's most powerful tropes. ${ }^{51}$ According to the Futurist artist Giuseppi Prezzolini, for example, [t]he cult of speed, the attraction to violent solutions...the exaltation of exclusively national feelings....all these are emotional attitudes that went from Futurism into Fascism without missing a beat. ${ }^{52}$

If one of the Futurists had seen the Arco dei Fileni (and perhaps some of them did), the 'passéism' of its decorative features and the 'static, grave, oppressive' character of its 'pyramidal' form and 'horizontal lines' would certainly have filled them with revulsion. ${ }^{53}$ But the Litoranea manifested everything that was beloved to Futurism. It slashed through a desert that had remained virtually unchanged since the fifth century $\mathrm{BCE},{ }^{54}$ and which had until then been traversable only by camel, under the guidance of a nomad, that supposed living symbol of civilisational backwardness. ${ }^{55}$ The road also decimated the journey-time between Tripoli and Benghazi, replacing the painfully long voyage by fortnightly steamer, ${ }^{56}$ accelerating the redeployment of troops, and bringing ever closer the exhilarating prospect of war - 'the world's only hygiene', according to the Futurist mantra. ${ }^{57}$ Perhaps most importantly, the Litoranea's high-speed penetration of the Arch invoked precisely the transformative capacity for 'intuition' that both Futurism and fascism valued so highly in the aggressive, muscular, male subjects of their common imagination.

The importance of intuition to the political aesthetics of Futurism was articulated most explicitly by the painter and sculptor Umberto Boccioni. Drawing heavily on the philosophy of Henri Bergson and Georges Sorel, Boccioni argued that it was the capacity to intuit an object's potential

\footnotetext{
50 'The Battle of Florence - Great Futurist Serata at the Verdi Theatre, December 12, 1913 - A Condensed (Physical and Spiritual) Report on the Battle - Marinetti's Speech,' Lacerba, 15 Dec. 1913, in G. Berghaus (ed.), F. T. Marinetti: Critical Writings, trans. D. Thompson (2006), 175.

${ }^{51}$ T. M. Marinetti, M. Carli \& E. Settimelli, 'Artistic Rights Championed by the Italian Futurists: A Manifesto to the Fascist Government', L'Impero, Mar. 1923, quoted in G. Prezzolini 'Fascism and Futurism', 3 Jul. 1923, in Rainey et al, supra note 49, 275 at 276.

52 Prezzolini, supra note 51, 275.

${ }^{53}$ A Sant'Elia, 'Futurist Architecture', 11 Jul. 1914, in L Rainey et al, supra note 49, 98 at 198. Emphasis in the original. Sant'Elia's target was precisely the 'neoclassical' architectural style that the Arco dei Fileni exemplified. As his manifesto continued, for instance: '[t]he new beauty of cement and iron is profaned by the superimposition of carnivalesque decorative encrustations that are justified neither by structural necessity nor by our tastes, encrustations that take their origins from Egyptian, Byzantine, or Indian antiquities, or from that stupefying efflorescence of idiocy and impotence that has taken the name of neoclassicism' (at 201, emphasis in the original).

${ }^{54}$ Kenrick, supra note 6, at 155.

${ }^{55}$ Fuller, supra note 33 , at 3.

${ }^{56}$ Wright, supra note 2, at 122.

${ }^{57}$ Marinetti, supra note 49 , at 51.
} 
for movement through time and space which distinguished the true (i.e. Futurist) artist. ${ }^{58}$ For example, in his Unique Forms of Continuity in Space (1913), Boccioni sought to express a 'fourth dimension in painting and sculpture' comprised of the three dimensions of volume together with an object's 'potential unfolding' in time, as intuited by the artist. ${ }^{59}$ The aesthetic gestures which expressed this fusion of time and space into a 'fourth dimension' aimed explicitly to 'awaken the beholder's intuitive capacities and actively transform consciousness'. 60 'In contrast with other proponents of the fourth dimension,' Antliff points out, 'Boccioni assimilated this spatial concept into the Futurists' highly politicized campaign to renew Italy':

The Futurist correlation of the fourth dimension with a Bergsonian spatial-temporal flux made up of 'force forms' and 'force lines,' unfettered by the limitations of three-dimensional space or measured 'clock' time, fused with a political program premised on intuition and an antimaterialist call for national regeneration and imperialist expansion. ${ }^{61}$

If any of the Futurists did have the opportunity to zoom through the Arch along Litoranea, they would hardly have missed the transformative potential of that experience. The road's sole purpose was, after all, to facilitate the accelerated movement of a mechanised object (ideally a tank) through both the space of the 'uncivilised' desert and the multiple centuries referenced by the Arch. From a Futurist perspective, therefore, the subject-passenger of such a vehicle could not fail to have been transfigured into one capable of intuiting - and hence participating in - fascist Italy's expansionist project.

Finally, of course, the Litoranea symbolised the domination and incorporation of Libya - a cause close to Futurism's heart. Marinetti, for example, had been profoundly impressed by the cutting-edge military technologies he witnessed as a war reporter during the Italo-Ottoman War. In his La Battaglia di Tripoli, he described Captain Carlo Piazza, history's first war pilot, singing joyfully while spraying 'rounds of lead into the torrential sea of the enemy army'. ${ }^{62}$ When, in 1923, Marinetti wrote an open letter to the 'Head of the New Italy', urging Mussolini to 'unleash Italian youth... in the conquest of an Italian Empire', he reproduced part of a 1911 manifesto in which he had congratulated the (liberal) Italian government on having 'finally become Futurist' through its annexation of Libya.

\footnotetext{
58 U. Boccioni [1914], Pittura e scultura Futuriste (Dinamismo plastico) (1997). See H. Bergson [1934], The Creative Mind: An Introduction to Metaphysics, trans. M. L. Andison (1946); G. Sorel [1908], Reflections on Violence (2004).

${ }^{59}$ Quoted in M. Antliff 'The Fourth Dimension and Futurism: A Politicized Space', 82 The Art Bulletin (2000), 720 at 724.

$60 \mathrm{lbid}$, at 727 .

$61 \mathrm{lbid}$, at 720 .

${ }^{62}$ F. T. Marinetti, La battaglia di Tripoli (26 Ottobre 1911) (Eidzioni Futuriste di 'Poesia' Milano 1912): 45-46 [my translation]. My sincere thanks to Tomaso Ferrando for tracking down a copy of this text for me.
} 
'[O]ur slim peninsula', he wrote, 'is swollen with creative genius, and has the right to govern the world'.63

The Litoranea, then, embodied precisely the accelerated expansionism and murderous attitude to 'tradition' so beloved of Futurism, and so influential for the political aesthetics of fascism. As the avenue through which the agents of Italian authority crossed the colony at a mechanical velocity which ploughed straight through any putative camel caravan, the road was clearly designed - among more obvious functions - to encourage Libya's native inhabitants to internalise the 'truth' of their supposedly anachronistic way of life, and of the futility of resisting their incorporation, both psychic and somatic, into the fascist imperial order. As Balbo declared in 1938: '[t]he image of the cabila or tribe wandering in the desert at the orders of its chief, according to the ancient traditions dating back to the great migrations and the barbarian invasions, will [soon] be no more than a distant memory in [Italy's] new Libyan provinces'. ${ }^{64}$

\section{Space.}

The dual temporality of the Arco/Litoranea, simultaneously 'classical' and 'futurist', was complemented by a spatial rationale which linked together three of Italian fascist imperialism's most distinctive concepts: spazio vitale; imperialismo demografico; and the idea of the quarta sponda, which characterized the Libyan coast as Italy's 'fourth shore'. In distinct but often overlapping ways, all three ideas sought to overlay the formal integration of coastal Libya into Italy in 1939 with a series of synthetic images, and in this way to embed the union between state and colony into the affective reality of the Mediterranean.

While fascism may have realised this goal most completely, the idea that Libya had once been, and should again be, an integral part of Italy was born much earlier than 1922. Soon after Italy's 'unification' (late for European standards) in 1861 with the publication of a series of widely disseminated sociological and criminological investigations into the causes of the crippling 'backwardness' of the Mezzogiorno (the Italian South). Studies such as Alfredo Niceforo's L'Italiana barbara contemporanea ('Contemporary Italian Barbarism') attributed this backwardness not to underdevelopment or traditionalism, but rather to racial inferiority. ${ }^{65}$ As Lucia Re points out, the 'shocking parallels perceived by the criminality, promiscuity, degeneracy, laziness, superstition, and squalor of the South and what was thought to be dark, barbaric, unevolved Africa' came increasingly

\footnotetext{
${ }^{63}$ F. T. Marinetti, M. Carli \& E. Settimelli 'The Italian Empire (to Benito Mussolini - Head of the New Italy)', 25 Apr. 1923, in Futurism: An Anthology (n X): 271-75 at 274.

${ }^{64}$ I. Balbo, speech to Volta Congress, 4-8 Oct. 1938, quoted in C. G. Segrè, Fourth Shore: The Italian Colonization of Libya (1974), 104.

${ }^{65}$ A. Niceforo, L'Italiana Barbara contemporanea: Studi sull'Italia del Mezzogiorno (1898). 
to be explained on the grounds that Italian Southerners were 'Southerners were...primitive or "dark" Mediterraneans - racially African and Camitic or Semitic' while Northerners 'were Aryan or Germanic and Slavic'. ${ }^{66}$ For many, establishing an overseas empire represented the best, if not the only solution to the twin problems of Italy's thwarted great power ambitions and haemorrhaging emigration problem - both closely related to the 'Southern question'. By the last decades of the nineteenth century, however, there was little of the world's surface left to claim, leading one Senator lament that 'the possibility of Italy being completely barred from the Orient and imprisoned in the Mediterranean makes [one] think of an animal which...enclosed in an iron circle, kills itself'. ${ }^{67}$ As the Ottoman Empire's reputation as the 'sick man of Europe' solidified, and as its European credentials began, in turn, to crumble, Tripolitania, Cyrenaica and Fezzan, just across 'our sea' (according to the Roman trope of mare nostrum) offered an obvious 'solution' in the form of an imperial outlet for Italy's 'surplus population' ${ }^{68}$ Half a century later, in 1932, the veteran Blackshirt Dino Grandi (Ambassador to Britain at the time) was articulating the same lament, though in an updated form: Italy, a nation 'confined and held captive within a closed sea', was being denied its rightful spazio vitale. $^{69}$

This narrative of expansionist right stemming from material necessity, almost as old as the Italian state itself, was reinforced after 1922 by fascism's identification as a proletarian project. Yet this sensibility, too, had pre-fascist roots. For example, in a famous speech delivered during the 1911-12 'Libyan War', the poet Enrico Pascoli depicted Italy as la grande Proletaria ('the great Proletarian'). ${ }^{70}$ This powerful maternal figure, Pascoli declared, had at last 'found a place' for the workers she was being forced to send abroad: 'a vast region bathed by our sea'. ${ }^{71}$ Pascoli claimed that North Africa's Islamic conquerors had 'seized' these territories illegitimately, 'close[ing] off, without cultivating it, land that is necessary and workable for all men, taking bread, foodstuffs, clothes and homes from the greater collective' - i.e. Italy, 'the great martyr of nations'. ${ }^{72}$ The conquest of 'Libya' would, Pascoli argued, be doubly transformative: re-civilising these formerly Roman territories while simultaneously resolving Italy's social fragmentation: in the 'lists of the glorious dead, of the wounded, rejoicing in their luminous wounds' was drawn 'the entire geography of Italy'. ${ }^{73}$ Libya as 'naught but an extension' of Italy 'connected by the familiar sea road', Pascoli declared, invoking the

\footnotetext{
${ }^{66} \mathrm{Re}$, supra note 31 , at $20-21$.

67 Senator Viteslleschi (1885), speech before the Chamber of Deputies, 1885, quoted in Fuller, supra note 33 , at 44 .

68 On the international legal history of the idea of 'surplus population', see A. Orford, 'Surplus Population and the History of International Law', Kent Law School, Centre for Critical International Law (CeCIL) Annual Lecture, 30 Nov. 2017;

${ }^{69}$ D. Grandi, Speech before the Senate, 4 Jun. 1932, quoted in MacCartney \& Cremona, supra note 5, at 284-85.

${ }^{70}$ A. M. Baranello, 'Giovanni Pascoli's 'La grande proletaria si è mossa: A Translation and Critical Introduction', 2 California Italian Studies (2011), 5.

71 Ibid., 8.

72 Ibid., 11.

73 'Ibid., 10.
} 
legend of a lost Roman road said once to have linked Sicily with Tripolitania. ${ }^{74}$ In Libya, Italians would be able to 'farm their own property, on the soil of the Motherland', where '[t]he laws they voted for will safeguard them'. In this way, 'Libya' was cast as an amputated limb whose legal reattachment would bring about the unification of the 'motherland'.

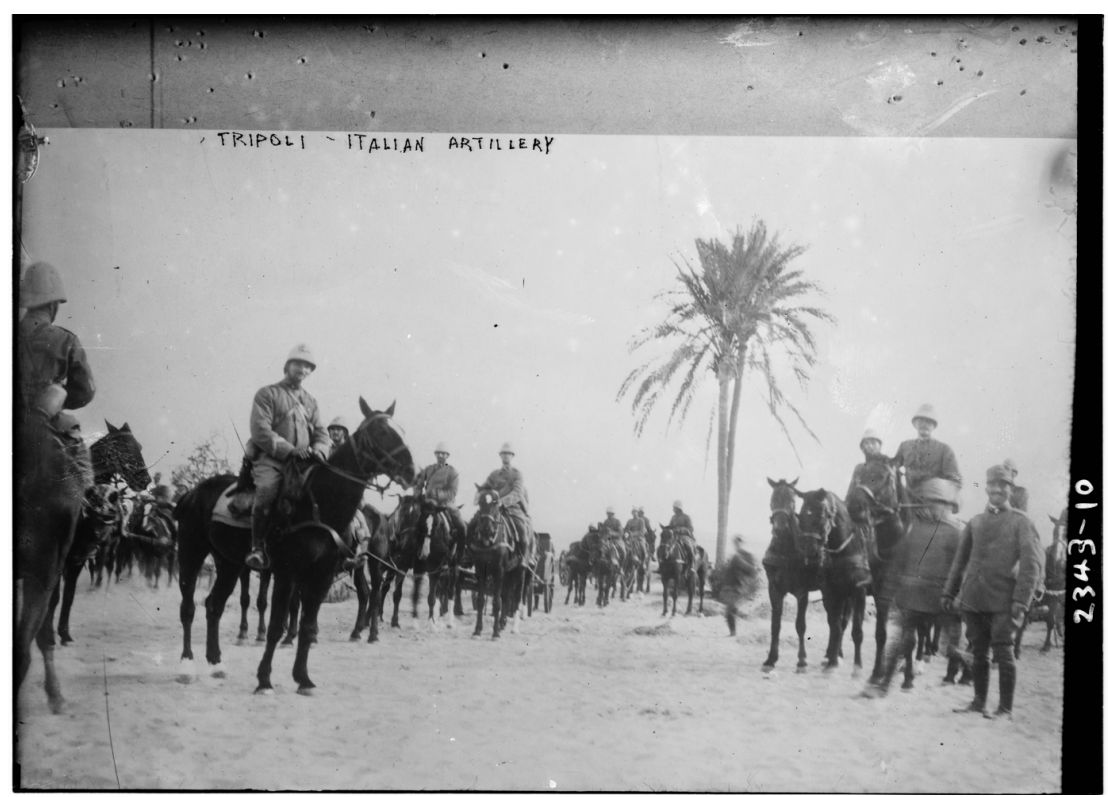

Figure 3: Italian artillery in Tripoli during the Italo-Ottoman War, 1911-12. Photo: Bain News Service, courtesy of the United States Library of Congress Prints and Photographs Division.

Under fascism, this proletarian spatiality morphed into the policy of 'demographic colonialism', even if, prior to 1931, when the Libyan resistance was finally crushed, this policy met with limited success. In 1938, however, a decree was issued, at Balbo's insistence, articulating a plan to settle no less than twenty thousand Italian colonists (the so-called ventimila) in Libya every year for five years. ${ }^{75}$ With the initiation of this policy, the fascist state took full control over the settlement of Libya for the first time. ${ }^{76}$ The land that was allocated, with much fanfare, to the settler families who arrived in Libya under its aegis had been appropriated under a series of laws that had first been instated in Tripolitania, under the governorship (1921-25) of Giuseppe Volpi. This legislation provided for the transferal of all 'uncultivated' land to the public domain, and for the confiscation of land held by 'rebels'. ${ }^{77}$ Just as Pascoli had hoped of the original appropriation of Libya, Balbo saw in imperialismo demografico a tool which could craft the Italian state into a homogenous whole - this time with a strongly corporatist character. Even the design of the farm houses which the settlers found waiting for them was called upon to reflect this objective. “'Traditional” in appearance' with 'clear, but non-local references to Italian vernacular[s]', these

\footnotetext{
${ }^{74} \mathrm{Re}$, supra note 31 , at 24-25.

75 R.d.I. 17 May 1938, n. 701. See Segrè, supra note 64, at 103.

76 Ibid., 94.

77 Decreto governatoriale, 18 Jul. 1922, ser. A, n. 660; Regio decreto 15 Nov. 1923, n. 3204; Decreto governatoriale 11 Apr. 1923, ser. A, n. 320. See Segrè, supra note 64, at 49.
} 
houses were designed specifically to emphasise '[the] settlers' belonging to the Italian nation rather than to any one region'. ${ }^{78}$

Despite the many continuities which, in Libya, connected the imperialism of the 1930s with the imperialism of Italy's liberal era, however, the insistence on the incorporation of coastal Libya was distinctively fascist. Where liberal administrations had constructed Libya as Italy's foil, and Libya's local population as uncivilised intruders, fascism's aim was to integrate Libya and Libyans into a unified Italian space ordered on the basis of hierarchy rather than dialectical opposition. The image of Libya as Italy's 'fourth shore' - in addition to its three other Mediterranean (Tyrrhenian, Adriatic and Ionian) coasts - was central to this idea, ${ }^{79}$ anchoring Italy's 'right' to spatial expansion not only in the limitations of a territory deemed too small for its vigorously expanding population but also in the specific history of the ocean into which the Italian peninsula thrust itself. Reinforced by the architectural trope of Mediterraneità, fascist Italy's imperial vision was one in which its social deeply fragmented core territory and scattered imperial possessions could be transformed into a single body. This was an altogether different spatial rationale from that which lay behind the classic 'salt water' model associated with liberal imperialism, in which title to territory was claimed on the basis of an insurmountable otherness.

Under Balbo's governorship this incorporative logic reached a new extreme with the decision to integrate Tripolitania and Cyrenaica fully into metropolitan Italy, while at the same time enhancing the legal protections given (in theory) to local customs. ${ }^{80}$ At Balbo's behest, a decree of 9 January 1939 - the 'crowning piece of legislation in the plan to create a quarta sponda' - transformed coastal Libya into Italy's nineteenth region. ${ }^{81}$ This territorially integrationist move was accompanied by a parallel series of measures aimed at achieving greater social integration between settlers and 'natives'. As the first families of the ventimila set sail on 28 October 1938 (the sixteenth anniversary of the March on Rome), they were left in no doubt as to their position at the vanguard of fascism's mission to give 'proletarian Italy' an 'outlet for its exuberant life'. ${ }^{82}$ Their role in concretising the juridical integration of Libya with Italy was captured by the poet Adriano Grande. 'No one cries any more', Grande wrote, because, 'The sea is ours / We cross it as if it were a piazza / And where we land / We still find Italy'. ${ }^{83}$ Upon arrival, the settlers found everything waiting for them, from model villages to seeds and farming equipment. The process of settlement was overseen by a series of colonisation companies, in many cases the very same institutions (such as the National Fascist

\footnotetext{
${ }^{78}$ Fuller, supra note 33, at 195.

79 Segrè, supra note 64, at xvi. The image of Italy as '[l]a grande Patria dalle quattro sponde' came, as so often, from D’Annunzio. See 'La canzone dei trofei' (1911) reprinted in A. Andreoli \& N. Lorenzini (eds.), supra note 31 , at $676-77$.

80 McLaren, supra note 40, at 168.

81 Segrè, supra note 64, at 105; 201, n. 15.

${ }^{82}$ A. Lessona, Minister for Italian Africa, speech of 19 May 1937, quoted in C. G. Segré, 'Italo Balbo and the Colonization of Libya', 7 Journal of Contemporary History (1972), 141 at 141. See Segrè, supra note 64, at 107.

${ }^{83}$ Quoted in Segrè, supra note 64, 109. See A. Grande, Poesie in Africa (1938).
} 
Institute for Social Security) involved in the reclamation of Italy's own swamps and other peripheral areas. This only underscored, once again, the legal, institutional and spatial relationship between Italy's apparently endless double-project of self-colonisation through colonial conquest. ${ }^{84}$

The local population of Libya was not excluded from this process of hierarchical social (in)corporatisation. On the contrary, the initiation of 'intensive demographic colonialism' coincided with the start of a new phase in their relationship with Italy, symbolised by Mussolini's decision to style himself 'protector of Islam'. ${ }^{85}$ The inauguration of this new image was, in fact, the primary purpose of Mussolini's second trip to Libya in 1937. This visit reached its climax in a ceremony held on 18 March, two days after the unveiling of the Arco and Litoranea. Urging the crowd to pass on his words 'through your towns and villages, right into the tents of the nomads', Mussolini proclaimed fascist Italy's wish 'to demonstrate sympathy towards... Muslims the world over'. 'Soon, with its laws' declared, 'Rome will show how anxious it is for your future welfare'. ${ }^{86}$ Mussolini's strategy here, according to the historian John Wright, was to offer supposedly "defenseless Muslims a true "Roman" (and thus universal) champion against the pusillanimous colonialism of the two leading Western democracies', Britain and France. ${ }^{87}$ Accordingly, a new decree was passed extending the privileges that had previously been reserved for settlers to 'natives', who became eligible to apply for government subsidies to fund agricultural reclamation and development projects. ${ }^{88}$

These changes to the property law in colonial Libya were mirrored by alterations made to the various forms of legal personality that were available to 'native' Libyans. Under Balbo's governorship, a new system of 'parallel' cultural development was instituted, which maintained pre-existing legal protections with respect to language, customs and religion, but replaced protections for 'tribal' structures with 'economic and political institutions similar to those of Italian nationals' ${ }^{89}$ The similaryet-different status of the Italiani mussulmani compared with the settlers (Italiani metropolitani) soon came to be legible in the most concrete elements of daily existence. The 'centres' that were built for 'resettled' Libyan farmers, for example (many of them by di Fausto), ${ }^{90}$ presented 'postcard-perfect images of North Africa Settlements' with their 'arcades and minarets'. Yet in doing so, as Fuller points out, they also reduced these features to their 'essential signifiers' which that presented Libya's Arab and Berber population with a series of 'artificial renderings of the very social configuration [the] Italians had uprooted'. ${ }^{91}$ Then, in 1939, a new law brought into being three classes of Italian citizen in Libya. Until that time, full Italian citizenship had been available, upon application, to all of Libya's inhabitants. Now they were divided into cittadini metropolitani (a status available only to Italians);

\footnotetext{
84 Ibid., 89-90.

${ }^{85}$ Wright, supra note 2 , at 125.

${ }^{86}$ Quoted in ibid.

87 Ibid.

88 RD 3 April 1937, no. 896. See Segrè, supra note 64, at 105.

89 Ibid., 104.

${ }^{90}$ Fuller, supra note 33, 193.

91 Ibid., 191-93.
} 
cittadini italiani libici (the default citizenship for 'natives'); and cittadini italiani speciali. This last 'special' status aimed at fulfilling another of Mussolini's 1937 pledges: to reward Libyan veterans who had been drafted in to fight in the Ethiopian war, and other loyalists, ${ }^{92}$ in the interests of creating 'an elite leadership sympathetic to the Italians'. ${ }^{93}$ Along with other measures (such as the broadcasting of Arabic programmes stressing the 'benefits of "Roman" justice' on Radio Bari) the fascist administration sought to bring into being 'the docile cooperation and goodwill of its Muslim subjects', who would occupy a secure but peripheral position within the fascist body corporate 'as workers in the more menial tasks of empire-building, as clerks and minor civil servants in the colonial administration, and as soldiers in the increasingly likely event of another world war'. ${ }^{94}$ With the partitioning of vast tracts of land previously used for grazing, 'shifting cultivation', suani (oasis gardens) and genanat (dry farms), Libya's new indigenous lease-holders were required by law to transform themselves from nomadic subsistence pastoralists (in the main) into settled and integrated owners and exchangers of private property. The devastating effects on the delicately balanced pre1911 subsistence system and social order supplemented those of fascism's brutal final push for dominance in Libya, completed six years earlier, with the use of tactics from public hangings to starvation to appalling concentration camps. ${ }^{95}$ According to some estimates, barely 50 percent of Cyrenaica's pre-1922 Bedouin population remained alive by the time of Mussolini's offer of 'protection'. 96

What connection, then, did these changes have with the nexus between the Arco and the Litoranea? According to the historian Caudio Segré, '[t]he construction of the Litoranea Libica was the physical counterpart of [the] administrative unity' brought about by coastal Libya's rhetorical and legal transformation into Italy's 'fourth shore'. ${ }^{97}$ Viewed against the background of these legal changes, the Arch/Litoranea offered a joint symbol of the distinctive integrated-yet-segregated spatial logic of social life in fascist Libya. Roaring through the Arch, a passenger in the late 1930s would have seen an inscription and a carved panel on either side of her flash past - one celebrating the completion of the road; the other the founding of the 'New Roman Empire' (see Fig. 2). The first panel showed 'the land surveyors with their pith helmets and their drawings in the foreground'; in the background, 'Arab workmen with sledge-hammers, stone-crushing machinery and the mineralrailway trucks'. Behind them was 'a camel-train bringing water in barrels'. The foreground of the panel opposite, meanwhile, was 'occupied by the Duce... at the head of his troops, saluting the Re

\footnotetext{
92 Segrè, supra note 64 , at 210 n. 11.

93 Ibid.

${ }^{94}$ Wright, supra note 2, 125-26.

95 Segrè, supra note 64, at 144-47. See generally Ahmida, supra note 3 . On the resistance movement in Tripolitania, see A. Del Boca Mohamed Fekini and the Fight to Free Libya, trans. A Shugaar (2011).

96 Ilan Pappé, The Modern Middle East (2005), 28.

97 Segrè, supra note 64 , at 88.
} 
Imperatore (Vittorio Emanuele III)'. Behind the King were 'the Hills of Rome with their monuments' and above them, 'a farmer ploughing the land'. 98

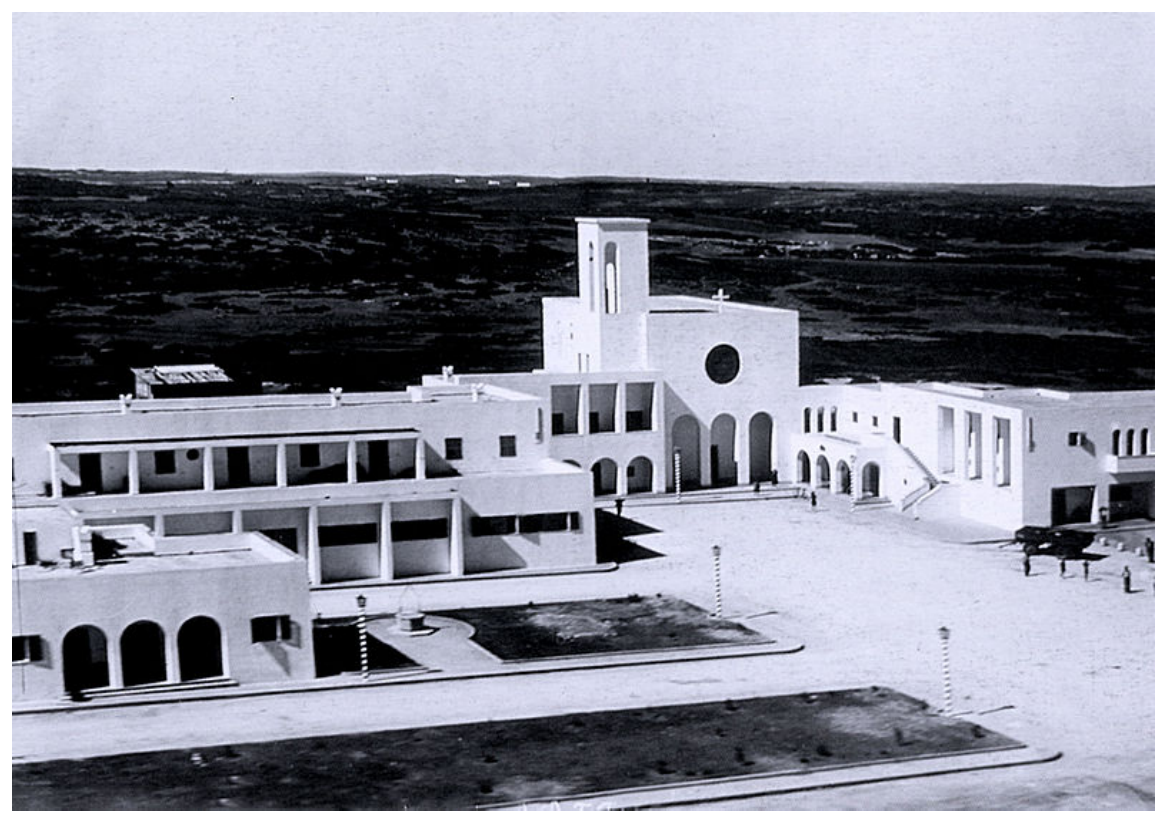

Figure 4: Villagio Cesare Battisti, Tripolitania, designed by Florestano di Fausto, 1 Jan. 1934. Source: Wikicommons.

The passenger would have been confronted, in other words, with a fleeting image in which agriculture and industry, metropole and colony, Arab labourer and Italian farmer, had been first constituted and then assembled as the integrated parts of a single socio-territorial machine. Had that passenger been the father of a settler family, the journey through the Arch (perhaps in a tractor) would have mirrored the spatial and legal changes that had just transformed him - almost overnight - from an impoverished sharecropper into a landowning farmer of the kind depicted on the carved panels at his flank. Indeed, as one enthusiastic visitor from the mainland described this territorial and social metamorphosis, the 'reclamation' of Libya had shifted Italian braccianti (day-labourers) up to the status of contadini (peasants), leaving the position of braccianti vacant for native Libyans to occupy themselves. Observing the settlers' adoption of local styles of dress and multiple dialects 'blending into a local patois' garnished with Arabic words and customs, it could at last be said, he continued, that Italians had formed themselves into a 'new race' - at once 'Mussolini's race, [a] fascist race, [a] colonial race'. ${ }^{99}$ Had the passenger in question been a soldier (trundling through in an armoured vehicle), or a tourist (speeding through in a motorcar), meanwhile, they would certainly have felt dwarfed by the sheer scale of the Arch, while at the same time exhilarated at the speed at which it disappeared as they sped away along the smooth new asphalt. The message - that of the absolute superiority of the collective over the individual - was clear.

\footnotetext{
${ }^{98}$ Kenrick, supra note 6 , at 156.

${ }^{99}$ G. P. Callegari, I villaggi libici (1941), 32-36, quoted in Fuller, supra note 33, at 184.
} 


\section{Subjectivity}

The first two sections of this article have unpacked some of the ways in which fascist legality was expressed in and reflected back from the physicality of colonial Libya, and from the intersection between the Arch and the road specifically. We have seen how the passage through the Arch was, like so much of fascist life, a carefully staged experience, designed to reinforce the juridical changes though which the Mussolini regime was then attempting to create a new set of hierarchically-ordered, synthetic legal subjectivities for Libya, Italy, and the world at large. On the surface, then, fascism's peculiarly 'monist' approach to law (international, colonial and domestic) could not be more distinct from doctrinal international legal thinking today, grounded as the latter is continues to be in a formally equal notion of subjectivity operating through a set of separate but equivalent scales ('sovereign' states, 'self-determining' peoples, individual bearers of 'universal human rights' and so on). ${ }^{100}$ If this is the case, we might ask whether fascism's experiments have anything at all to tell us about the relationship between doctrinal international law today and the kind of violence which Libya has been forced to experience on its path away from fascist colonialism towards 'sovereign statehood'?

I will use this section to suggest that, for all its pomposity and viciousness, fascism's officials, lawyers and philosophers accepted a truth about the concept of self-determining subjectivity or 'sovereignty', its logic and its material effects - a logic which present-day doctrinal international law denies. Like the architects of Libia Italiana's villages, monuments and roads, the engineers of fascism's peculiar corporatist-monist approach to domestic, colonial and international law understood that the connection between individual and international (legal) subjectivity was not merely 'analogous' (as the doctrine of international law assumes with its image of the state as individual 'writ large'101) but rather enforceable, interpellative and constitutive. In short, my suggestion will be that the act of thinking about and treating the state as macro version of the 'free' and 'equal' individual (the 'domestic analogy', whether in its fascist or liberal form) has predictable and deleterious effects on the distribution of wealth, power and pleasure - effects which fascism (and fascist international law) accepted and celebrated, but which liberalism (and liberal/present-day doctrinal international law) continues reject, if not consciously to obscure.

The crucial correspondence here concerns fascism's notorious state fetishism - a fetishism which international law shares wholeheartedly, if rather less stridently. In its doctrinal international legal form, this fetish is formally and very strictly egalitarian. Thus, while other, lesser 'international personalities' may exist, only states can be 'full' subjects of international law, possessed of the complete set of 'sovereign' rights and duties (including law-making powers) which cannot be

\footnotetext{
100 See, for an obvious example, UN Charter, supra, note 17, Preamble.

101 See E. de Vattel [1758] Le Droit des Gens, ou Principes de la Loi Naturelle, appliqués à la Conduite au Affaires des Nations e des Souvrains (1916), 2, para. 4; C. Bottici, Men and States: Rethinking the Domestic Analogy in a Global Age, trans. K. Whittle (2009); M Koskenniemi, From Apology to Utopia: The Structure of International Legal Argument (2006), 71-157.
} 
'restricted' in the absence of explicit consent, except in very exceptional circumstances (with the recent emergence of so-called jus cogens norms). ${ }^{102}$ By contrast, inter-war fascism attributed to the state a quasi-mystical capacity to surpass the temporal and spatial limits of individual existence by condensing the subjectivities of all 'men' into one - or, rather, into a hierarchy of 'ones', each of them nation-states with material capacities and therefore different sets of rights.

According to Mussolini, for instance - in a widely-read exposition published in the January 1935 edition of International Conciliation, the journal of the Carnegie Endowment for International Peace - the state was not a 'mere mechanical device for defining the sphere within which the individual may duly exercise his supposed rights', as assumed by the liberal understanding of the 'rule of law', but 'an inwardly accepted standard', the 'soul of the soul'. ${ }^{103}$ It was the state, he insisted, which allowed 'man' to '[transcend] the brief limits of individual life' by sublimating 'his' subjectivity in its collective, eternal 'personality'. ${ }^{104}$ Deploying a favourite Futurist trope, Mussolini described this 'spiritualised' capacity as an 'intuition', ${ }^{105}$ through which the state was able to connect the 'living reality of the present' together with 'the past and above all with the future', and in this way to lead 'men from primitive tribal life to that highest expression of human power which is Empire'. ${ }^{106}$ As in Boccioni's celebration of Futurist intuition, fascist theory took for granted that the temporal and spatial dynamic of international 'personality' was one of inexorable expansion - an expansion, indeed, that fascist Italy soon set about realising through its annexation of the Ethiopian Empire (1936), Albania (1939), parts of Yugoslavia (1941) and elsewhere. Woven through this fascist conception of the citizen, the state, the empire and even of the 'family of nations' was a corporatist understanding of liberty or self-determination: the integration of the individual into the 'state hierarchy' was said to enhance (rather than to diminish) '[h]is freedom to act', which, 'no longer restricted to the sphere of private interests', could 'now assert itself within the entire social system'. ${ }^{107}$

Transposing this theory of individual subjectivity to the international realm, fascist jurists and diplomats embarked on the project of reorganising the global order along hierarchical lines just as Italian society was being reorgnaised domestically. ${ }^{108}$ Prior to its withdrawal from the League of Nations in 1937, for instance, Italy repeatedly denounced the 'absurdity' of the 'principle of absolute

\footnotetext{
${ }^{102}$ For the classic exposition, see e.g. The Lotus Case (France vs Turkey), Judgement No. 9, PCIJ Rep. Series A, No. 10, 1927, at 18.

${ }^{103}$ B. Mussolini, 'The Political and Social Doctrine of Fascism', 16 International Conciliation (1935), 5 at 1314.

104 Ibid., 21-22.

105 B. Mussolini, Fascism: Doctrine and Institutions (1935), 7.

${ }^{106}$ Mussolini, supra note 103, at 10-11; 21-22.

107 U. Spirito 'Corporativismo as Absolute Liberalism and Absolute Socialism' (1932), in J. T. Schnapp, O. E. Sears \& M. G. Stampino (eds.), A Primer of Italian Fascism, trans. J. T. Schnapp (University of Nebraska Press Lincoln \& London 2000): 154-64 at 163

108 Ibid., 154.
} 
juridical parity among all States', as codified in the Covenant, ${ }^{109}$ on the grounds that states were 'differentiated....by their historical responsibilities'. ${ }^{110}$ Only if the League were 'properly directed by a master hand' would it 'rise from its present impotence to give decisiveness and prestige to itself and tranquility to the international system'. ${ }^{111}$ Having failed in its efforts to 'reform' the League (which it abandoned in 1937 in the wake of the 'Abyssinia Crisis'), Italy attempted to bring this new, hierarchical world order into being in collaboration first with Nazi Germany in the 1939 'Pact of Steel'112 and then with both Germany and Imperial Japan in the 'Tripartite Pact' of 1940 (later joined by Hungary, Romania, Slovakia, Bulgaria, Croatia and nearly also by Thailand). ${ }^{113}$ The objectives of these states in concluding these treaties was explicitly that of 'striv[ing] with united effort for the securing of their spazzio vitale/Lebensraum and the maintenance of peace', ${ }^{114}$ and of establishing in this way a 'new order' in Europe, led by Italy and Germany, and another in Asia, led by Japan. ${ }^{115}$ This project was, of course, eventually terminated upon the victory of the 'united nations' in 1945 (although it should be recalled that this victory was secured not only by enormous Western European military sacrifices and American capital, but also by the gigantic scale of the resources deployed by the Soviet Union, then firmly in the grip of Josef Stalin; by the carpet-bombing of German cities by Allied forces; and by the world's first and only use of nuclear weapons against Japan). However, when observed from the perspective of those communities which found themselves in fascist, occupied and/or collaborationist Africa, Europe, Asia and the Pacific between 1922 and 1945 (from the perspective of 'native' Libyans, for example), it would be difficult to write that 'new order' off as a complete failure.

Once again, however, it is important to keep in mind that this fascist internationalist dream did not come from nowhere. The idea that territorial expansion was the necessary corollary of truly 'sovereign' statehood, for instance, had long been a familiar aspect of the logic of liberal diplomatic relations before fascism arrived on the scene (as we have already seen in the Italian context). For instance, when the British imperialist, entrepreneur and statesman Cecil Rhodes declared in 1895 that in order to save the forty million inhabitants of the United Kingdom from a bloody civil war, we colonial statesmen must acquire new lands for settling the surplus population, to provide new markets for the goods produced in factories and mines', ${ }^{116}$ he only articulated, for Britain, something that was obvious to all of Europe's imperial 'sovereign equals'. ${ }^{117}$ The legitimising rationale of fascist

\footnotetext{
1091919 Covenant of the League of Nations, 27 LNTS 350, Art. 10. Although see R Parfitt, The Process of International Legal Reproduction: Inequality, Historiography, Resistance (Cambridge: CUP, forthcoming, 2018).

${ }^{110}$ B Mussolini, speech of 1 Nov. 1936, quoted in MacCartney \& Cremona, supra note 5, at 247.

111 B Mussolini, Sunday Dispatch, 31 Dec. 1933, quoted in MacCartney \& Cremona, supra note 5, at 245.

1121939 Pact of Friendship and Alliance between Germany and Italy, Berlin, 22 May 1939 ['Pact of Steel'].

1131940 Three-Power Pact between Germany, Italy, and Japan, Berlin, 27 Sep. 1940 ['Tripartite Pact'].

114 Pact of Steel, supra note 112, Preamble.

115 Triparite Pact, supra note 113, Arts. 1 and 2.

${ }^{116}$ Quoted in V. I. Lenin, 'Imperialism, the Highest Stage of Capitalism,' in H. M. Christman (ed.), Essential Works of Lenin: "What Is to Be Done?" and Other Writings (1987), 229.

117 See generally S. Pedersen, The Guardians: The League of Nations and the Crisis of Europe (2015).
} 
expansionism was, in other words, identical to that of European imperialism, but for one thing: fascism's willingness to annex 'sovereign', European territory (as well as less-than-sovereign, extraEuropean territory) in order to obtain the resources deemed 'vital' to its continued existence. With this willingness, fascism manifested its contempt not only for the axiom of sovereign equality but also for the international law's 'unrealistic' Europhilism. ${ }^{118}$ It also shattered the white supremacism which underpinned the European colonial project into a far more complex but equally brutal hierarchy of racial supremacy, according not only Africans, Arabs and Indigenous peoples but also European Jews, Slavs, Roma and others could legitimately be subordinated and, if necessary, liquidated. ${ }^{119}$

Today, by contrast, and as noted at the start, colonialism is considered wholly illegitimate as a matter of international law. ${ }^{120}$ However, the arrival of the customary right of peoples to selfdetermination in the late-twentieth century meant that satiating the 'vital needs' of a state's increasingly numerous or wealthy population (more commonly referred to, today, in terms of a healthily expanding 'domestic market') by means of territorial expansion is no longer a legitimate option (whether beyond or within Europe), the same does not apply when it comes to the state's right to capture of resources other than land for the same purpose. On the contrary, the idea that an available 'supply' of 'natural resources' coupled with the 'demand' associated with a national population's burgeoning wants and needs constitutes an enforceable 'right' to expansion into 'emerging markets' to which almost any form of opposition (in the form, say, of tariffs or quotas) is prohibited constitutes the bedrock assumption of the contemporary international trade and investment regime. That regime's institutions have been endowed with effective channels for countering such resistance in the form of the state-state and investor-state dispute mechanisms, for example in the World Trade Organisation, the North Atlantic Free Trade Agreement and the Comprehensive and Progressive Agreement for Trans-Pacific Partnership (TPP11). ${ }^{121}$ Only the most powerful states - those with the biggest 'markets' and the largest reservoirs of resources - can get away with resisting some of the rules they so rigorously enforce amongst their peers. ${ }^{122}$

Approached from a twenty-first century doctrinal starting-point, the inexorably expansionist logic (from colonialism to neo-colonialism) of international law's core subject, the self-determining or sovereign state, is difficult to see. According to the treaties, custom and case law that regulate the coming-into-being and 'intercourse' of states under international law, it is simply a fact of life in the 'internationa community' that some communities happen to be sovereign states, possessed of an 'external' right to self-determination, while others just happen to exist within theose states, protected

\footnotetext{
118 See N. Berman, 'Beyond Colonialism and Nationalism? Ethiopia, Czechoslovakia, and "Peaceful Change",' 65 Nordic Journal of International Law (1996), 421.

119 See e.g. D. Woodley, Fascism and Political Theory: Critical Perspectives on fascist Ideology (2010), 187210.

120 See supra, note 18.

121 See generally D. Deese (ed.), Handbook of the International Political Economy of Trade (2014).

122 See e.g. 'Donald Trump Says He Won't Back Down on Plan to Impose Steel, Aluminium Tariffs despite Republican protests', ABC News, 6 Mar. 2018.
} 
by the 'internal' equivalent of that right. ${ }^{123}$ With these rights in place, borders can be assumed to remain 'defined', populations 'permanent', and states 'peace-loving' at heart. ${ }^{124}$ In practice, however, the pattern according to which rights of 'external' and 'internal' self-determination have come to be distributed among the world's communities and territoires is neither random nor neutral. Instead (as Marxist, 'Third World', Indigenous, queer and feminist legal scholars continue to argue), this pattern has been determined, over the course of five centuries, by the accumulation and distribution of resources - most obviously, 'natural', economic, financial and technical resources, but also, and just as importantly, the many other forms of epistemological capital (as we might call it), deriving from the racist, gendered, heteronormative and other discriminatory structures which continue to order our everyday lives. ${ }^{125}$

What a chronotopic investigation into fascist material practices of colonialism and international law contributes to this critique is a slight change in focus, from the origins of inequality to its mechanisms of perpetuation. In a world in which the only subjective relationship with any normative value is that between the individual and the state (conceived as a macro individual), there is, after all, only one way to overcome the physical limit which death - mortality - places on 'true' selfdetermination. This is, of course, through the establishment of a 'bloodline': procreation; the founding of a family; then a tribe; then a 'nation' and ultimately the formation of a nation-state. This means, of course, that the extension of self-determining subjectivity in time must go hand-in-hand with the expansion of self-determining subjectivity in space, as generations multiply and begin to find themselves in competition for resources. This trajectory, with its 'survival of the fittest' logic, was axiomatic for Mussolini, Boccioni, Rhodes - for inter-war Futurists and fascists and pre-war imperialists generally, as we have seen.

But which view is correct? Is the 'international community' a stable global patchwork collection of sovereign equals, comfortably producing and exchanging resources with one another in order to provide for the material needs of their 'fixed' populations? ${ }^{126}$ Or is contemporary international legal order better characterised as a vast accumulation of annexations, colonisations, peace treaties and boundary agreements, whose unspoken violence and suppressed tensions are inexplicably absent from doctrine to which international lawyers direct themselves when working out questions of jurisdiction, sovereignty and responsibility? ${ }^{127}$

To respond to this question, let me return, one last time, to this article's comparison between the physical dimensions and repercussions of point $30^{\circ} 31^{\prime} 00^{\prime \prime} \mathrm{N}, 18^{\circ} 34^{\prime} 00^{\prime \prime} \mathrm{E}$ in 1937 (the Arch/Litoranea

\footnotetext{
123 See e.g. Reference re: Secession of Quebec, Advisory Opinion of 20 Aug. 1998, Supreme Court of Canada, 2 S.C.R. 297, para. 138.

124 UN Charter, supra note 17, Art. 4(1).

125 See generally Eslava, supra note 25.

1261933 Montevideo Convention of the Rights and Duties of States, Art. 1.

127 See e.g. Montevideo Convention, Art. 3; and for a detailed doctrinal analysis, J. Crawford, The Creation of States in International Law, $2^{\text {nd }}$ Ed. (2004).
} 
nexus) and its physical dimensions and their repercussions in the years since 2011 (the disputed Ra's Lanuf refinery and its surroundings). If we assume that Libya is, indeed, the 'sovereign equal' of every other state in the international community (including those which regularly continue to carry out air strikes within its territory), then the chronotopes of this point at these two moments, eight decades apart, do seem to be very different from one another. As I argued in Section 1, the temporality of fascist legality was a double-temporality, simultaneously circling back to the purported universalism of classical antiquity (symbolised by the arch-ness and kitchy eclecticism of the Arco) and dragging 'anachronous' aspects the 'now' of the late 1930s into a violently accelerating future (the epitome of which was the technical spectacle of the Litoranea itself). By contrast, the temporality of international legality today is typically narrated, in the doctrine of international law, as singular, linear and progressive; as a long chain of 'breaks' and 'renewals' in which the past is continually being left behind in order to validate the present. ${ }^{128}$ In spatial terms, meanwhile, as I outlined in Section 2, the legal thinking and practice of fascist Italy was concerned with the incorporation of those peoples it had drawn within Italian jurisdiction into an integrated, macro-micro hierarchy of subjects, domestic, colonial and international - a story retold in the extended route of the Litoranea and in the Arch's decorations. By contrast, I suggested that the spatiality of orthodox international thinking today operates, in theory, on the basis of independent formal equality - even when, in Libya's case, a full-scale military intervention, only tenuously consensual, is in the process of being authorised and executed. ${ }^{129}$

Fascist subjects, meanwhile, were, as we saw, differentiated in terms of their rights and duties on the basis of assumptions about their physical and psychological attributes, corresponding to the particular degree of deference expected of them towards fascism's corporatist legal order. In colonial Libya, for example (as the Arch's reliefs illustrated), the bottom rungs of the socio-legal ladder were occupied by dominated colonial subjects; the middle rungs by obedient settlers (farming families and workers); while the top rung was inhabited by men like Grandi, Balbo and, of course, Mussolini, the leader of the all the Blackshirts. It was upon their supposedly virile, aggressive, disciplined-yetaudacious subjectivity that the ideal of the ultra-fascist 'new man' was modelled, just as it was in the 'macro' version of this 'personality', imagined as being embodied in the super-sovereign fascist state itself. In its most potent manifestations, then, the leading subjects of the fascist legal imagination were unashamedly violent, hierarchical and expansionist. ${ }^{130}$ By contrast, international law's subjects, micro and macro, are all, in theory, equally free, pacific and orderly. ${ }^{131}$

Which of these two visions of subjectivity corresponds most closely to that which point

\footnotetext{
${ }^{128}$ N. Berman, 'In the Wake of Empire', 14 American University International Law Review (1999), 1521.

129 Res. 1973, supra note 8, Preamble. See also e.g. Montevideo Convention, supra note 127, Arts. 3-5; UN Charter, supra note 17, Arts. 1(2); 2(1).

${ }^{130}$ See R. S. Parfitt, 'The Anti-Neutral Suit: International Legal Futurists, 1914-2017', 5 London Review of International Law (2017), 87.

131 UN Charter, supra note 117, Art. 1(2).
} 
$30^{\circ} 31^{\prime} 00^{\prime \prime} \mathrm{N}, 18^{\circ} 34^{\prime} 00 " \mathrm{E}$ (2011 ff) calls into being and reflects back? Let us think through this question chronotopically once again. Spatially, this 'location' is today largely off limits to all but the allies of whichever militia, security force or army happens to have successfully fought off its contenders. Many of these are implacably hostile either to the international community's plans for Libya's future (as with Haftar's Libyan National Army), or indeed (as with IS) to the 'dazzling and deceptive slogans' they attribute to international law per se. ${ }^{132}$ As the images broadcast back from this point by bulletproofed war photographers reveal (see Fig. 5), the contrast between the state-of-the art oil refinery (constructed in and through a multitude of international contracts between the Libyan state and various multinational companies) and its devastated surroundings is, indeed, nothing short of 'dazzling'. ${ }^{133}$ Conduct an image search for 'Ra's Lanuf' and one can see the refinery's narrow concrete chimneys, swathed in pale-green rigging, shimmering in the heat a mile or so back from the remains of the Litoranea, surrounded by a skid-marked desert strewn with rubbish and shrapnel. This juxtaposition, it might be argued, offers a graphic illustration of the mismatch between international law's doctrinal expectations about Libya's subjectivity as a 'sovereign state' recently liberated from authoritarianism on the one hand, and the material reality of Libya's century-long 'transition' towards sovereign equality on the other.

We might begin, here, by noting that, just as fascist Italy set out legally to incorporate coastal Libya into the 'motherland' as Italy's 'fourth shore', so the aim of Operation Unified Protector was explicitly that of 'integrat[ing] Libya fully into the 21st-century world economy in transparent ways where Libya's oil wealth is used for the benefit of all of Libya's citizens', by a different mechanism: that of 'privatising some of [its] state monopolies'. ${ }^{134}$ Underpinning the legitimacy of this twenty-first century incorporative project was the presumed (or, one might say, 'intuited') desire of the Libyan people to participate as equals in the global economy (routinely depicted as the primary aim of the 'Arab Spring' uprising of 2011 in general). ${ }^{135}$ To be a 'free' and 'equal' individual within a 'sovereign' state was the universal 'birthright of every man, woman and child', as US Secretary of State Hillary Clinton asserted in March 2011 when making the case for intervention before the UN Human Rights Council. ${ }^{136}$ Released from Qaddafi's peculiar and deeply authoritarian form of socialism (described

\footnotetext{
${ }^{132}$ Amirul-Mu'minin Abu Bakr al-Husayni al-Qurashi al-Baghdadi, 'A Message to the Mujahidin and the Muslim Ummah in the Month of Ramadan', Al Hayat Media Centre, 1 Jul. 2014, at www.gatestoneinstitute.org.

${ }^{133}$ The operating contracts for the Ra's Lanuf and neighbouring Es Sider facilities are held by Libya's staterun National Oil Corporation (NOC) in partnership with a host of multinationals including Trasta Energy, based in the UAE, the French company Total, Norway's Saga Petroleum and a US consortium consisting of Marathon Oil, Hess and ConocoPhilips (V Walt 'Big Oil Companies in the Cross Fire as Libyan Violence Erupts' Fortune, 5 Mar. 2015; 'Company Profile, Mabruk Oil Operations,' at mabrukoil.com). Its storage tanks were built by the Swiss firm Vitol ('NOC and Vitol to Build Storage Tanks in Libya', Vitol.com, 11 Jun. 2008). 134 Senior State Department official, speaking at a press briefing in advance of US Secretary of State Hillary Clinton's visit to Libya, E. Labott, 'Clinton makes Unannounced Visit to Libya', CNN.com, 18 Oct. 2011. 135 See A. Hanieh, Lineages of Revolt: Issue of Contemporary Capitalism in the Middle East (2013); e.g. A Hanieh 'Egypt's "Orderly Transition"? International Aid and the Rush to Structural Adjustment' Jadaliyya, 29 May 2011, at www.jadaliyya.com

${ }^{136}$ H. Clinton, Address to the UN Human Rights Council, 3 Mar. 2011.
} 
in the New York Times as 'a mixture of utopian socialism, Arab nationalism...[and] Third World revolutionary ideology... with a streak of Bedouin supremacism' ${ }^{137}$ ), Libya was expected, in 2011 , to rise from the flames fully equipped with 'democratic processes and institutions, good governance, rule of law, national reconciliation and respect for human rights and fundamental freedoms'. ${ }^{138}$ When we look at photographs of Ra's Lanuf today, it is this vision of the 'free' and 'equal' Libyan citizen which the looming presence of Ra's Lanuf refinery (and its anxious but invisible international investors) demands. ${ }^{139}$

However, as the bleak landscape that surrounds the refinary's burned-out tanks and abandoned buildings cannot bears witness, that demand continues to echo out across desert without a reply or, at least, without the reply it was expecting. Libya and Libyans have not, it seems, taken up the opportunity that was offered to them by the 'international community'. Far from lining up at the door of the refinery to offer their labour 'freely' to the global economy, many of them have been compelled either to join one of the militias or to flee from them to Europe or elsewhere. This was not, however, part of the plan. State populations, after all, are meant to be 'settled'. Having been re-constituted as the subjects of a 'real' - market - democracy that is supposed to (as Clinton explained) 'deliver results for [its] citizens', ${ }^{140}$ Libyans are expected look to their own elected representatives to provide them with a 'level playing field' upon which to compete, on formally equal terms, for the world's resources (including their own). Having been liberated not only from fascism and colonialism but now also from socialism, Libyans citizens are, naturally, prohibited from competing on someone else's pitch. So, too, are the millions of other citizens who are fleeing, likewise, through Libya, from poverty and violence in Syria, Iraq, Bangladesh, Côte d'Ivoire and elsewhere. ${ }^{141}$

These so-called 'economic migrants' are cast as alien intruders by many of Libya's fellow sovereign states, including those who participated so enthusiastically in Operation Unified Protector. ${ }^{142}$ Having disembarked from the Tripolitanian or Cyrenaican coast (in some cases, from the Ra's Lanuf terminal itself ${ }^{143}$ ), tens of thousands of individuals - aspiring settlers moving in the wrong direction along the mythical Roman road - are once again being accused of 'taking bread, foodstuffs, clothes and homes from the greater collective'. ${ }^{144}$ This time, however, their theft arises not only from their historic occupation of land without cultivating it (or, in this case, without extracting oil from it) efficiently, but also and more recently from their efforts to escape the damage and chaos into which that land has gradually been thrust in the name of their own individual and collective

\footnotetext{
${ }^{137}$ M. Bazi, 'What did Qaddafi's Green Book Really Say?' New York Times, 27 May 2011.

${ }^{138}$ Clinton, supra note 136.

139 See e.g. IMF, Libya: Staff Report for the 2013 Article IV Consultation, 2 May 2013, 1.

${ }^{140}$ Clinton, supra note 136.

141 See the statistics regularly updated on the UNHCR's 'Mediterranean Situation' page, at www.unhcr.org

142 See e.g. L. Dearden, 'UK Accused of Trapping Refugees in Warzone After Boris Johnson Vows to Stop "Illegal Migrants" Crossing Med', The Independent, 23 Aug. 2017. See I. Mann, Humanity at Sea: Maritime Migration and the Foundations of International Law (2016).

143 M. Micallef, 'Exclusive: Interpol Issues ISIS Alert on Mediterranean', Migrant Report, 3 Jul. 2015.

144 Pascoli, supra note 70, at 11.
} 
emancipation. $^{145}$

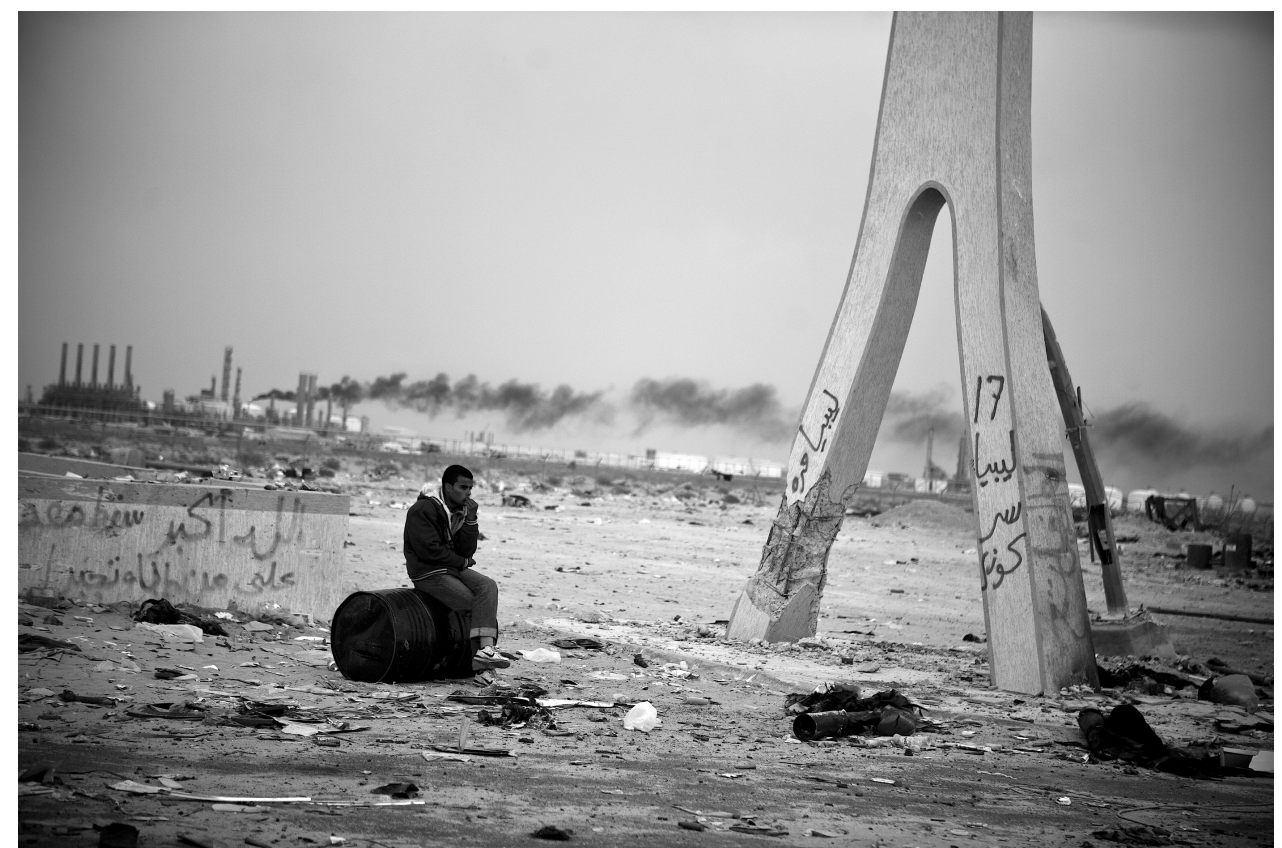

Figure 5: A revolutionary and a refinery confront the fallout. Ra's Lanuf, 2011. Photo @ Benjamin Lowy/Getty Images.

Ironically (or perhaps not) one consequence of what the 'refugee crisis' has been a strong resurgence of support for the supposedly outdated and discarded judicial and political institutions of fascism. ${ }^{146}$ This is not, however, the connection between 'colonial' and 'free' Libya that I want to draw attention to. The more salient connection, I suggest concerns the hierarchical position that contemporary Libya continues to occupy, not just in spite of but because of the formal egalitarian of the international community into which it has just been so violently (re)integrated. The rationale behind that violence and that hierarchy are clear: if competitive 'free' and 'equal' individuality within a 'sovereign' state really is the 'birthright of every man, woman and child', ${ }^{147}$ then Libya's ongoing 'failure' as a sovereign state can only stem, ${ }^{148}$ not from the intervention itself, but rather from Libyans' failure to manifest the maturity and rationality that are deemed necessary to 'reject violence, uphold equality, and...play by the rules of democracy'. ${ }^{149}$ This is indeed the message which Libya and Libyans have been receiving from the 'international community' as the civil war continues. At a summit in mid-2015, for example, France, Germany, Italy, Spain, the UK and the US urged 'all Libyan decision makers to show in this crucial moment [the] responsibility, leadership and courage' necessary to sign the Skhirat Agreement, then in the process of being drafted by the UN's (Italian)

\footnotetext{
145 Res. 1973, supra note 8, Preamble.

${ }^{146}$ See e.g. F. Finchelstein \& F. Bosoder, 'Is Fascism Returning to Europe?' New York Times, 13 Dec. 2015.

${ }^{147}$ Clinton, supra note 136.

${ }^{148}$ Andrew Engel, 'Libya as a Failed State: Causes, Consequences, Options', 24 Washington Institute Research Notes (Nov. 2014), at WashingtonInstitute.org.

${ }^{149}$ Clinton, supra note 136.
} 
Special Representative to Libya, Bernardino Léon. ${ }^{150}$ When the 'international community' reconvened in Paris on 2 October 2016 to address the ongoing crisis, representatives from Egypt, Germany, Italy, Qatar, Saudi Arabia, Spain Turkey UAE, UK and the USA' were present, along with 'UN Special Envoy Martin Kobler and EU foreign policy chief Federica Mogherini'. No Libyans, however, had been invited. When questioned on this point, 'French officials' suggested it had been an accidental oversight resulting from 'the rapid organising of the event'. ${ }^{151}$

\section{Conclusion: Empire.}

This essay has compared the material dimensions of the location marked by the coordinate $30^{\circ} 31^{\prime} 00^{\prime \prime} \mathrm{N}, 18^{\circ} 34^{\prime} 00^{\prime \prime E a t ~ t w o ~ d i f f e r e n t ~ m o m e n t s ~ i n ~ t i m e, ~ o f f e r i n g ~ t h i s ~ c o m p a r i s o n ~ u p ~ a s ~ a ~ s o b e r i n g ~}$ example of international law's failure to shake off the legacy of European imperialism. Beyond this, however, I have also sought to suggest that the specifically fascist imperial history of this 'imperial location' reveals something particular about the relationship between international law and violence. This 'something' concerns the inherently expansionist logic which animates international law's 'sovereign' subjects. As Libya's experience illustrates only too vividly, these subjects relate to each other not as 'peace-loving' neighbours of equal standing, but instead as rivals and predators. The problem, of course - a problem which fascism accepted as a fact of 'sovereign' life, but which present-day international legal doctrine is reluctant to confront - is that states cannot all be permitted to 'grow' in this way, whether through territorial conquest or through the 'liberalisation' of their 'access' to an increasing array of 'resources', from newly 'formalised' Third World 'housing markets' to 'indigenous knowledge' and beyond.

It is this expansionist logic, I suggest, which constitutes the precise connection between the spatio-temporality of $30^{\circ} 31^{\prime} 00^{\prime \prime} \mathrm{N}, 18^{\circ} 34^{\prime} 00^{\prime \prime} \mathrm{E}$ in 1937 , and the subjects which were interpellated by that spatio-temporality under the fascist regime, and the temporal, spatial and subjective features of point $30^{\circ} 31^{\prime} 00^{\prime \prime} \mathrm{N}, 18^{\circ} 34^{\prime} 00^{\prime \prime} \mathrm{E}$ today. One may have been frighteningly orderly, impeccably groomed and 'colonial'. The other may be physically devastated, frighteningly chaotic and 'sovereign'. Nonetheless, in a context in which expansion has always been, by definition, the only route to a form of statehood that 'delivers', both the previous life and the contemporary existence this 'imperial location' offer concrete reminders of what it has meant, for Libya and Libyans, to become contestants in a zero-sum game which they cannot win, but will never be permitted to lose.

\footnotetext{
150 Joint Statement on Libya by the Governments of France, Germany, Italy, Spain, the United Kingdom, and the United States, Washington D.C., 30 June 2015, at www.state.gov

151 'Paris meeting on Libya fails to make progress; Libyans not invited', Libya Herald, 3 Oct. 2016.
} 


\section{Table of Figures}

Figure 1: The Arco dei Fileni and the Via litoranea libica. Nazi propaganda image, 23 Sep. 1940. Photo: Berliner Verlag/Archiv @ DPA Picture Alliance/Alamy Stock Photo.

Figure 2: The Arco dei Fileni. Nazi propaganda image, 1937 @ Photo: Sueddeutsche Zeitun/Alamy Stock Photo.

Figure 3: Italian artillery in Tripoli during the Italo-Ottoman War, 1911-12. Photo: Bain News Service, courtesy of the United States Library of Congress Prints and Photographs Division.

Figure 4: Villagio Cesare Battisti, Tripolitania, designed by Florestano di Fausto, 1 Jan. 1934. Source: Wikicommons. 20 Figure 5: A revolutionary and a refinery confront the fallout. Ra's Lanuf, 2011. Photo @ Benjamin Lowy/Getty Images. 29 